\title{
Strength and Durability Evaluation of Recycled Aggregate Concrete
}

\author{
Sherif Yehia*, Kareem Helal, Anaam Abusharkh, Amani Zaher, and Hiba Istaitiyeh
}

(Received October 9, 2014, Accepted April 6, 2015, Published online May 14, 2015)

\begin{abstract}
This paper discusses the suitability of producing concrete with $100 \%$ recycled aggregate to meet durability and strength requirements for different applications. Aggregate strength, gradation, absorption, specific gravity, shape and texture are some of the physical and mechanical characteristics that contribute to the strength and durability of concrete. In general, the quality of recycled aggregate depends on the loading and exposure conditions of the demolished structures. Therefore, the experimental program was focused on the evaluation of physical and mechanical properties of the recycled aggregate over a period of 6 months. In addition, concrete properties produced with fine and coarse recycled aggregate were evaluated. Several concrete mixes were prepared with $100 \%$ recycled aggregates and the results were compared to that of a control mix. SEM was conducted to examine the microstructure of selected mixes. The results showed that concrete with acceptable strength and durability could be produced if high packing density is achieved.
\end{abstract}

Keywords: recycled aggregate, concrete properties, physical properties, mechanical properties.

\section{Introduction}

Utilizing recycled aggregate is certainly an important step towards sustainable development in the concrete industry and management of construction waste. Recycled aggregate (RA) is a viable alternative to natural aggregate, which helps in the preservation of the environment. One of the critical parameters that affect the use of recycled aggregate is variability of the aggregate properties. Quality of the recycled aggregate is influenced by the quality of materials being collected and delivered to the recycling plants. Therefore, production of recycled aggregate at an acceptable price rate and quality is difficult to achieve due the current limitations on the recycling plants. These issues concern the clients about the stability of production and variability in aggregate properties. The main goal of the current research project is to investigate variability of aggregate properties and their impact on concrete production. Aggregate strength, gradation, absorption, moisture content, specific gravity, shape, and texture are some of the physical and mechanical characteristics that contribute to the strength and durability of concrete. Therefore, it is necessary to evaluate these properties before utilizing the aggregate. In this paper, properties of recycled aggregate from an unknown source collected over a period of 6 months from a recycling plant were evaluated. In addition, properties of concrete produced with $100 \%$ recycled aggregates were investigated.

Department of Civil Engineering, American University of Sharjah, Sharjah, United Arab Emirates.

*Corresponding Author; E-mail: syehia@aus.edu

Copyright ( $\odot$ The Author(s) 2015. This article is published

with open access at Springerlink.com

\section{Background}

\subsection{Economical and Environmental Impact}

The evolution in the construction industry introduces several concerns regarding availability of natural aggregate resources, as they are being rapidly depleted. Recent statistics showed the increasing demand of construction aggregate to reach 48.3 billion metric tons by the year 2015 with the highest consumption being in Asia and Pacific as shown in Fig. 1 (The Freedonia Group 2012). This increasing demand is accompanied by an increase of construction waste. For example, construction waste from European Union countries represents about $31 \%$ of the total waste generation per year (Marinkovic et al. 2010; Ministry of Natural Resources 2010). Similarly, in Hong Kong, the waste production was nearly 20 million tons in the year 2011, which constitutes about $50 \%$ of the global waste generation (Tam and Tam 2007; Lu and Tam 2013; Ann et al. 2013). Disposal in landfills is the common method to manage the construction waste, which creates large deposits of construction and demolition waste sites (Marinkovic et al. 2010; Tam and Tam 2007; Naik and Moriconi 2005). Efforts to limit this practice and to encourage recycling of construction and demolition waste in different construction applications led to utilizing up to $10 \%$ of the recycled aggregate in different construction applications (Marinkovic et al. 2010; Ministry of Natural Resources 2010; Naik and Moriconi 2005; European Aggregate Association 2010; Cement, Concrete, and Aggregates 2008; Tepordei 1999). Therefore, recycling has the potential to reduce the amount of waste materials disposed of in landfills and to preserve natural resources (Sonawane and Pimplikar 2013; Llatas 2011; Lu and Yuan 2011; Braunschweig et al. 2011; Marinkovic et al. 2010; Gupta 2009; Rao et al. 2010; Tam 2008; Topcu and Guncan 1995). 


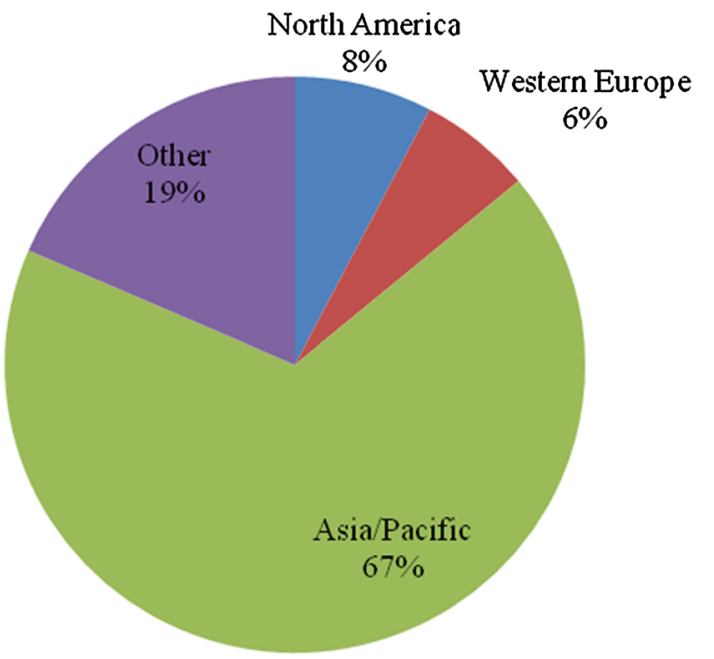

Fig. 1 Demand on construction aggregates worldwide (The Freedonia Group 2012).

\subsection{Properties of Recycled Aggregate Concrete}

Durability and other concrete properties are affected by the use of recycled aggregate in concrete mixes. Research efforts to introduce RA into the construction industry and to address their effects on properties could be classified to the following categories:

(1) Policies, cost and benefits: the goals are to standardize the use of RA in concrete, highlight the cost of capital investments and to emphasize environmental and economic benefits. Land protection and preservation of natural resources are the main benefits of utilizing recycled materials in the construction industry (Hansen 1986; Kartam et al. 2004; FHWA 2004; Oikonomou 2005; Tam and Tam 2007; EU Directive 2008/98/EC; Ministry of Natural Resources 2010; Marinkovic et al. 2010; Ann et al. 2013; Silva et al. 2014; Lu and Tam 2013; Bodet 2014).

(2) Evaluation of physical and mechanical properties of RA: absorption, aggregate texture (type of crushers, number of crushing stages), aggregate size and gradation, specific gravity, density, mortar content, percentage and type of contamination, aggregate strength and abrasion resistance are the main properties that affect utilizing RA in concrete production. Variation in the RA properties due to loading, different environmental conditions in addition to the crushing process, contamination and impurities such as wood and plastic pieces, affect concrete properties produced using RA. Mortar adhered to RA lead to lower density, high absorption, and high L.A. abrasion loss. In addition, sulphate and alkali contents cause expansive reactions which can be controlled if the maximum sulphate is in the range of $0.8-1.0 \%$ by mass and alkali content below $3.5 \mathrm{~kg} / \mathrm{m}^{3}$ (Tam et al. 2008; De Juan and Gutiérrez 2009; McNeil and Kang 2013; De Brito and Saikia 2013; Akbarnezhad et al. 2013; Silva et al. 2014).

(3) Mix design and proportioning: direct volume replacement, weight replacement and equivalent mortar replacement are some of the approaches that could be followed to design mixtures with RA. In addition, the mixing process can affect overall concrete properties. Both volume replacements and pre-soaking approaches showed improved properties of concrete produced with RA (Tam et al. 2007a, b; Cabral et al. 2010; Fathifazl et al. 2009; Knaack and Kurama 2013; Wardeh et al. 2014).

(4) Evaluation of fresh and hardened concrete made with RA: there are numerous efforts to evaluate fresh and hardened properties of concrete with RA. Optimizations to determine the percent of RA that could be used without affecting the short and long term performance were also investigated. Design equations based on data collected from many publications were also proposed. In general, the use of recycled aggregate led to reduction in all mechanical properties, in addition to influencing the fresh stage properties and concrete durability due to high absorption and porosity (Xiao et al. 2006; Yang et al. 2008; Kwan et al. 2012; Manzi et al. 2013; Akbarnezhad et al. 2013; Ulloa et al. 2013; Xiao et al. 2014; McNeil and Kang 2013; Silva et al. 2014).

(5) Improving durability of RA concrete: concerns about durability and the long-term performance of concrete with RA are hurdles that limit utilization of RA in many applications. Chloride conductivity, oxygen and water permeability, carbonation depth, alkaline aggregate reaction, sulphate resistance, shrinkage and creep performance, abrasion resistance and freeze resistance are some of the parameters that could be used as durability and long-term performance indicators of concrete material. In general, concrete made with RA showed less durability due to high pore volume which led to high permeability and water absorption. High water absorption is due to cement paste adhered on the aggregate surface. However, this can be countered by achieving saturated surface dry (SSD) conditions before mixing. This might not be practical in some cases of mass production. Therefore, aggregate absorption can be accounted for during the mix design stage by adjusting the mixing water that will be absorbed by the recycled aggregate. Surface coating was another approach to control absorption and improve properties (Olorunsogo and Padayachee 2002; Zaharieva et al. 2003; Levy and Helene 2004; Ann et al. 2008; Yang et al. 2008; Abbas et al. 2009; Thomas et al. 2013; Lederle and Hiller 2013; Fathifazl and Razaqpur 2013; Xiao et al. 2014; Ryou and Lee 2014). In addition, many research efforts showed that the use of supplementary cementitious materials (SCM) as a replacement for cement or addition by weight can improve concrete durability due to improvement of pore structure and reduction of the volume of macro pores. Fly ash (25-35\%), silica fume (10\%) and ground-granulated blast-furnace slag (up to $65 \%$ ) are the most commonly SCM which are used to improve concrete strength and durability properties (Berndt 
2009; Kou and Poon 2012; Amorim et al. 2012; Eisa 2014).

(6) Microstructure, interfacial transition zone (ITZ) and bond characteristics: close inspection of the interfacial transition zone (ITZ) showed porous microstructure which can be attributed to high porosity and high absorption capacity of the recycled aggregate. In addition, possible cracking due to crunching and processing and exposure to several chemicals and depositions of harmful substances on the surface of aggregate can lead to cracks in concrete and reduction in the bond between the cement and aggregate. The mixing process, less w/c ratio and addition of SCM can improve the ITZ and bond characteristics of recycled aggregate concrete (Otsuki et al. 2003; Poon et al. 2004; Tam et al. 2005; Evangelista and Brito 2007; Tabsh and Abdelfatah 2009; Xiao et al. 2012a)

Table 1 summarizes some of the findings, limitations and potential challenges in using recycled aggregate in concrete applications.

\section{Aggregates Used in the Study}

Quality and availability of recycled aggregate are the main factors towards stable use and introduction of recycled aggregate concrete to the construction industry. The crushed stone aggregate used in the study was obtained from a recycling plant which was established and directed towards reducing waste produced from the construction industry to provide an efficient alternative for the reuse of recycled aggregate. The waste is received and processed to produce several products; however, the main product is aggregate. The process involves crushing, separation of metals by a magnet, manual removal of other impurities (plastic, wood, etc..), and classification of aggregate to different grades based on particle size. The facility produces 5 grades that vary from fine aggregate (grade 5) to $63 \mathrm{~mm}$ particle size (grade 3 ). The percentage produced from each grade depends on the materials delivered to the facility; however, grades 1, 2, 4 and 5 represent about $80 \%$ of the plant production that ensure availability of these grades for the use in the construction industry.

\section{Experimental Program}

The main objectives of the experimental program were to (i) investigate variability of recycled aggregate properties and their impact on concrete production and (ii) evaluate properties of concrete prepared with $100 \%$ recycled aggregate. Therefore, the experimental program was divided into two phases; Phase 1 deals with evaluation of the aggregate properties and Phase 2 focuses on the evaluation of concrete mixtures utilizing $100 \%$ recycled aggregates. Figure 2 summarizes the experimental program and list of physical and mechanical properties included in the investigation. All results were compared to that of a control mix prepared with virgin aggregate (crushed lime stone). In addition, Scanning Electron Microscopy (SEM) was conducted to examine the microstructure of some samples to provide an idea about the bond strength between cement and aggregate and identify potential weak points within the mix.

\subsection{Phase 1: Evaluation of Aggregate Properties}

The recycling facility was the source of the recycled aggregate (RA) used in the investigation. Aggregate was collected at different time intervals to evaluate the effect of consistency and variability in the quality on concrete properties. Only four grades were included in the investigation, grade 1 (maximum size of $10 \mathrm{~mm}$ ), 2 (maximum size of $25 \mathrm{~mm}$ ), 4 (mixture of course and fine aggregate along with impurities) and 5 (fine sand). Grade 3 was excluded because of the particle size $(63 \mathrm{~mm})$. In this phase, several physical and mechanical properties of aggregate that are directly related to concrete properties were evaluated, as shown in Fig. 2.

\subsubsection{Results of Aggregate Evaluation}

Results of the physical and mechanical tests conducted on RA showed expected variations from virgin aggregate mainly due to the presence of mortar adhered on the aggregate which is reflected in the high absorption capacity of the aggregate. Figure 3 shows sample of different aggregate grades used in the study. Small percentage of impurities (wood and plastic chips) was found in the aggregate, such impurities are expected due to the recycling process.

Sieve analysis Four batches of RA were obtained from the recycling facility between December 2012 and April 2013. All batches went through the same evaluation to investigate any variability in production. Figure 4 shows the sieve analysis results of the RA and virgin aggregate (control) compared to the upper and lower limits specified by (ASTM C33/C33 M 2013a, ASTM C136 2011a). Although the gradation varies from that of the control and did not meet any ASTM grading requirements, there was a clear similarity in the gradation of the last 3 batches of each grade which indicates a consistent RA production. Additionally, the authors decided to use the RA to produce concrete without any alteration of the gradations already obtained from the plant. The reasons for the decision are to avoid additional costs and to utilize available gradations to achieve acceptable particle distribution.

Aggregate crushing value $(A C V)$ provides an indication of the aggregate strength. Aggregate with lower ACV is recommended to ensure that the aggregate will be able to resist applied loads. The test was conducted on coarse aggregate of different grades. The ACV is calculated as the ratio between the weight passing sieve 2.36 and the original weight. Values were in the range of 20-30, as shown in Fig. 5a.

Abrasion resistance is an indication of the aggregates' toughness. The Los Angeles (LA) test was conducted according to (ASTM C131 2006) and the test results are shown in Fig. 5b. The coarse aggregates in grade 4 had a higher 
Table 1 Effect of recycled aggregate on concrete properties.

\begin{tabular}{|c|c|c|}
\hline Durability & $\begin{array}{c}\text { Durability of Recycled Aggregate (RA) can be } \\
\text { influenced by coarse aggregate replacement } \\
\text { ratio, concrete age, w/c ratio, and moisture } \\
\text { content; generally, a lower w/c ratio generates } \\
\text { a more durable concrete mix. RA concrete is } \\
\text { less durable due to high porosity of recycled } \\
\text { aggregate. However, lower resistance to } \\
\text { ingress of certain agents might be } \\
\text { compensated by the combination of recycled } \\
\text { aggregate with } \mathrm{CO}_{2} \text { and chlorides which } \\
\text { reduces their penetration rates. SCM are used } \\
\text { to improve strength and durability of RA } \\
\text { concrete }\end{array}$ & $\begin{array}{l}\text { Thomas et al. (2013), Fathifazl and Razaquur } \\
\text { (2013), Kou and Poon (2012), Chen and Ying } \\
\text { (2011), Corinaldesi and Moriconi (2009), } \\
\text { Gonclaves et al. (2004) }\end{array}$ \\
\hline Compressive strength & $\begin{array}{c}50 \text { to } 100 \% \text { replacement of virgin aggregates } \\
\text { with recycled aggregate decreases the } \\
\text { compressive strength by } 5 \text { to } 25 \% \text {. However, } \\
\text { it was found that up to } 30 \% \text { virgin aggregate } \\
\text { can be substituted with RCA without any } \\
\text { effects on concrete strength. Strength gain for } \\
\text { RCA concrete is lower than normal aggregate } \\
\text { concrete (NAC) for the first } 7 \text { days. On the } \\
\text { other hand, fine RA has a more detrimental } \\
\text { effect on compressive strength than coarse } \\
\text { RA }\end{array}$ & $\begin{array}{l}\text { Malešev et al. (2010), Rahal (2007), Yehia } \\
\text { et al. (2008), Limbachiya et al. (2004), Xiao } \\
\text { et al. (2012b), Corinaldesi (2010), Rahal } \\
\text { (2007), Garg et al. (2013), Sim and Park } \\
\text { (2011) }\end{array}$ \\
\hline $\begin{array}{c}\text { Fresh concrete Properties: } \\
\text { Workability } \\
\text { Moisture Content }\end{array}$ & $\begin{array}{l}\text { More water is needed to achieve similar } \\
\text { workability to that of NAC due to higher } \\
\text { absorption capacity of recycled aggregate } \\
\text { which can be attributed to the presence of } \\
\text { impurities and attached cement hydrates. As } \\
\text { the RA content increase in the mix, the } \\
\text { workability reduces especially at lower w/c } \\
\text { ratio in their study found that the entrapped } \\
\text { air content was similar when compared to } \\
\text { normal concrete mix having a range of } \\
2.4 \pm 0.2 \% \text {. In fact, there is no significant } \\
\text { effect regarding the air content up to } 25 \% \\
\text { replacements }\end{array}$ & $\begin{array}{c}\text { Xiao et al. (2012b), Sagoe-Crentsil et al. } \\
\text { (2001), Tabsh and Abdelfatah (2009), Medina } \\
\text { et al. (2014), Qasrawi and Marie (2013), } \\
\text { Sagoe-Crentsil et al. (2001) }\end{array}$ \\
\hline Flexural strength & $\begin{array}{c}\text { Recycled aggregate has marginal influence on } \\
\text { flexural strength, some studies showed that } \\
\text { flexural strength reduction is limited to } 10 \% \\
\text { in RA concrete. Others indicated that RA } \\
\text { concrete has very similar flexural behavior } \\
\text { with virgin aggregate concrete }\end{array}$ & $\begin{array}{l}\text { Malešev et al. (2010), Xiao et al. (2012b), } \\
\text { Chen et al. (2010), Limbachiya et al. (2004) }\end{array}$ \\
\hline Modulus of elasticity & $\begin{array}{c}\text { Modulus of elasticity is greatly reduced by the } \\
\text { use of recycled aggregate; it can reach } 45 \% \\
\text { of the modulus of elasticity of corresponding } \\
\text { conventional concrete. This percentage } \\
\text { reduction varies based on the percentage } \\
\text { substitution. The } 45 \% \text { reduction was found } \\
\text { at } 100 \% \text { substitution, while up to } 15 \% \\
\text { reduction was observed at } 30 \% \text { substitution }\end{array}$ & $\begin{array}{l}\text { Vyas and Bhatt (2013), Xiao et al. (2012b), } \\
\text { Corinaldesi (2010) }\end{array}$ \\
\hline Split tensile strength & $\begin{array}{l}\text { A reduction of up to } 10 \% \text { in split tensile } \\
\text { strength was observed when virgin aggregate } \\
\text { was substituted with recycled aggregate. } \\
\text { Studies suggest that split tensile strength is } \\
\text { more dependent on the binder quality rather } \\
\text { than the aggregate type }\end{array}$ & $\begin{array}{l}\text { Malešev et al. (2010), Thomas et al. (2013), } \\
\text { Sagoe-Crentsil et al. (2001) }\end{array}$ \\
\hline
\end{tabular}


Table 1 continued

\begin{tabular}{|c|c|c|}
\hline Specific gravity and bulk density & $\begin{array}{l}\text { Padmini et al. (2009) found that the specific } \\
\text { gravity and bulk density are relatively low for } \\
\text { recycled aggregates when compared to fresh } \\
\text { granite aggregate (FGA). This is mainly due } \\
\text { to the high water absorption of the RA, as } \\
\text { mortar has higher porosity than aggregates; } \\
\text { hence RA absorbs more water than FGA }\end{array}$ & Padmini et al. (2009). \\
\hline Aggregate size & $\begin{array}{l}\text { Padmini et al. (2009) found that as the } \\
\text { maximum size of the RA increases, the } \\
\text { achieved strength increases }\end{array}$ & Padmini et al. (2009). \\
\hline Shrinkage and creep & $\begin{array}{l}\text { Shrinkage and creep deformation of RA } \\
\text { concrete are higher than those of } \\
\text { conventional concrete, } 25 \text { and } 35 \% \text { higher, } \\
\text { respectively. Percentage of substitution, size } \\
\text { and source of parent aggregate, mixing } \\
\text { procedure, curing, SCM and chemical } \\
\text { admixture affect shrinkage and creep of the } \\
\text { RA concrete. Recent studies showed } \\
\text { improved behavior could be achieved by mix } \\
\text { proportioning, low w/c ratio and curing }\end{array}$ & $\begin{array}{l}\text { Silva et al. (2015), Fathifazl and Razaqpur } \\
\text { (2013), Fathifazl et al. (2011), Henschen et al. } \\
\text { (2012), Domingo-Cabo et al. (2009), Xiao } \\
\text { et al. (2014). }\end{array}$ \\
\hline
\end{tabular}

\section{Experimental Program}

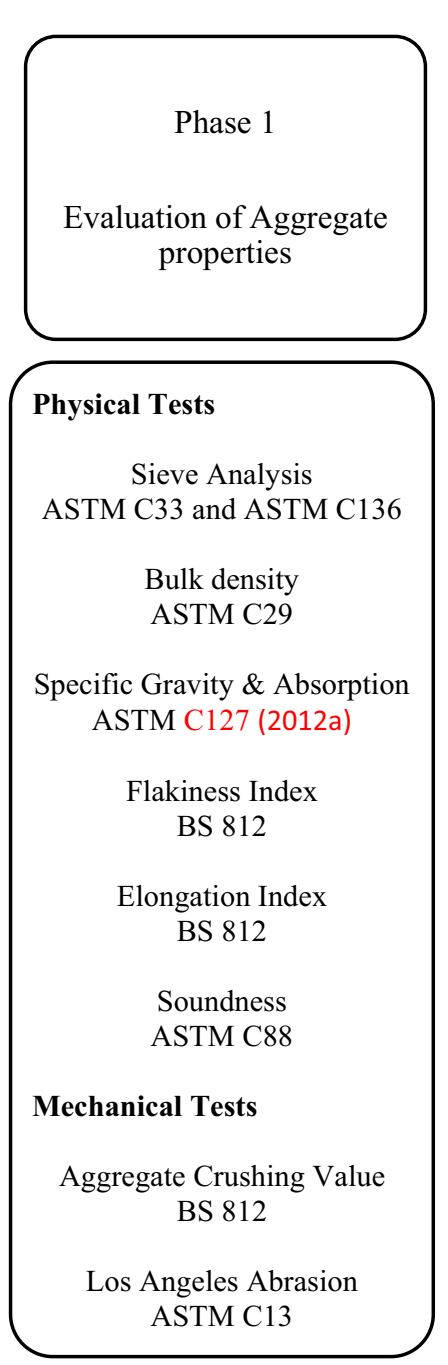

\section{Pahse 2}

Evaluation of concrete properties prepared with different grade combinations

Set 1 - Grades 1,2 and 5 -- 2 and 5 -- 1 and 5

Set 2 - Grades - 1,4 and 5 -- 1 and 4

Set 3 - Grades 4

Fig. 2 Summary of the experimental program conducted in the investigation. 


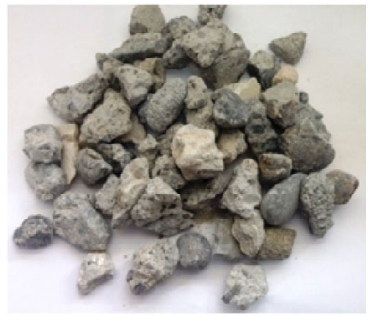

(a) Grade 1 - maximum size of $10 \mathrm{~mm}$

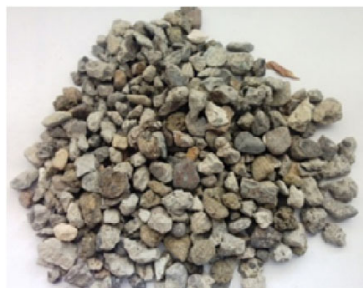

(b) Grade 2 - maximum size of $25 \mathrm{~mm}$

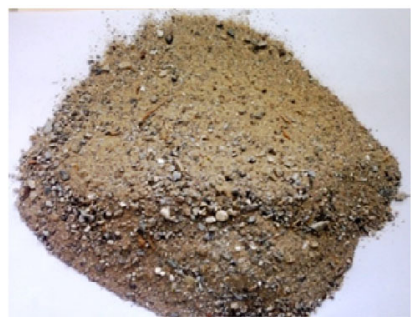

(c) Grade 5 - Fine sand

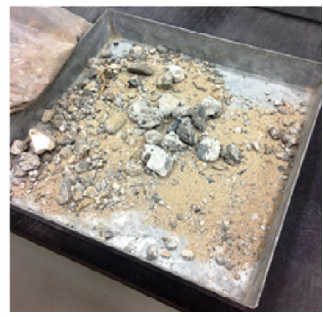

(d) Grade 4 - Mixture of course and fine aggregate along with impurities such as wood and plastic pieces
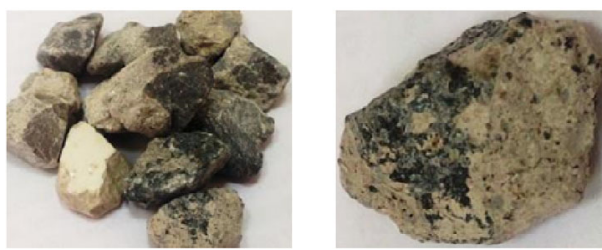

Close inspection of the aggregate

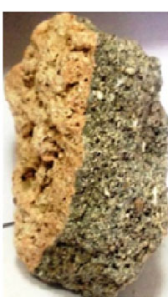

Aggregate Texture
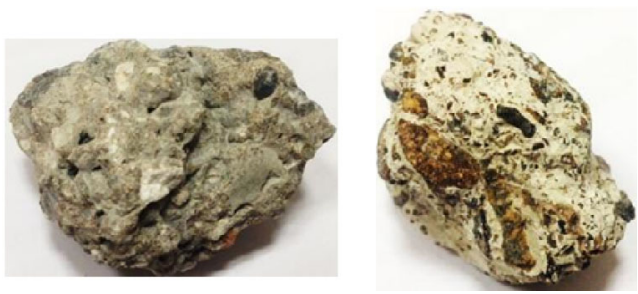

Small size aggregate connected by mortar

Fig. 3 Different grades of recycled aggregates produced by the recycling facility.

percentage of weight loss, close inspection showed weak aggregate (small-sized aggregate covered with mortar, Fig. 3d).

Absorption grades 1 and 4 showed high absorption capacity (up to $8 \%$ ) while it was in the range of $3 \%$ for grade 2 and 5. These values indicate high porosity which will require special considerations during mixing to achieve workability and to control water demand.

Soundness Soundness test was conducted according to (ASTM C88. 2013b) using Sodium Sulphate salt. Coarse aggregates from Grades 2 and 4 were sieved to different sizes and the retained on each sieve was exposed to four cycles of soaking in the solution and drying in air. Figure $5 \mathrm{~d}$ shows percentage of the weight loss in size $9.5 \mathrm{~mm}$. There was about $20 \%$ weight loss in grade 2 ; however, the loss in grade 4 was in the range of 20 to $40 \%$. The reasons for this high loss in volume from exposure to deicing agents are weak strength and high porosity of the recycled aggregate as indicated by high absorption.

\subsubsection{Comparison Between Properties of the Virgin Aggregate and RA}

Table 2 shows a sample of the results obtained from the physical and mechanical tests of recycled aggregate in December 2012 and April 2013 respectively. The last three batches indicated a similar trend with slight variations in properties, while aggregate gradation and particle sizes were maintained. However, there was an increase in the specific 


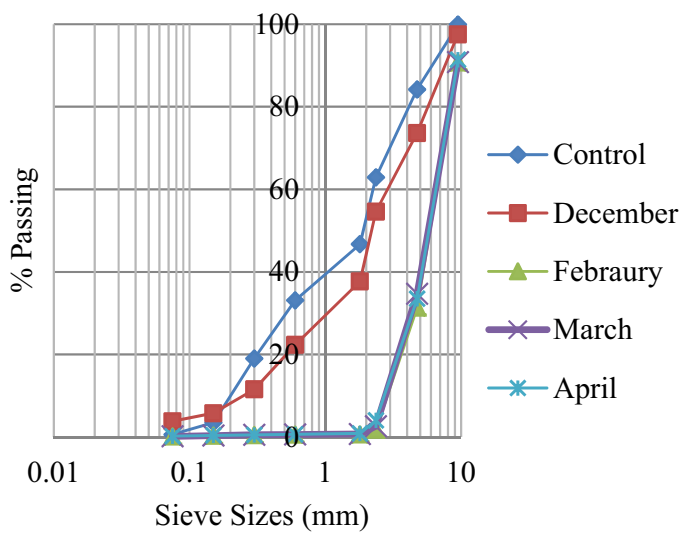

(a) Grade1

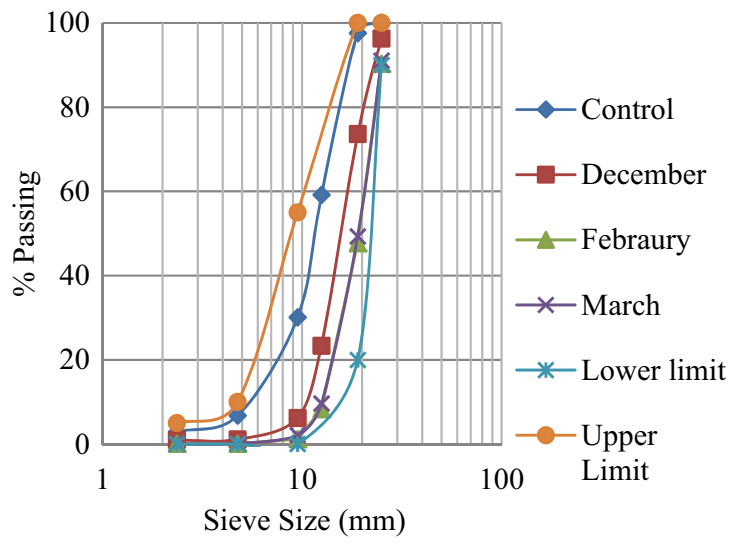

(b) Grade2
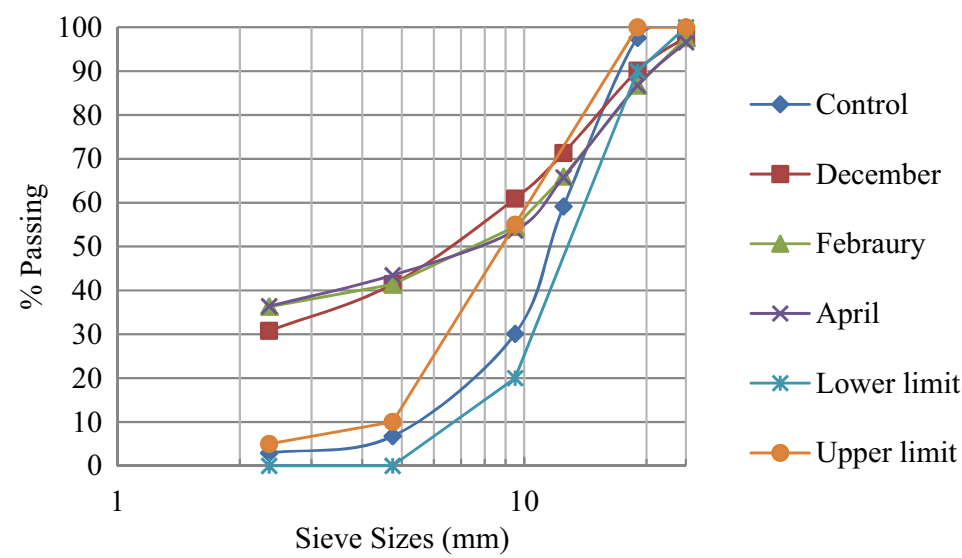

(c) Grade 4
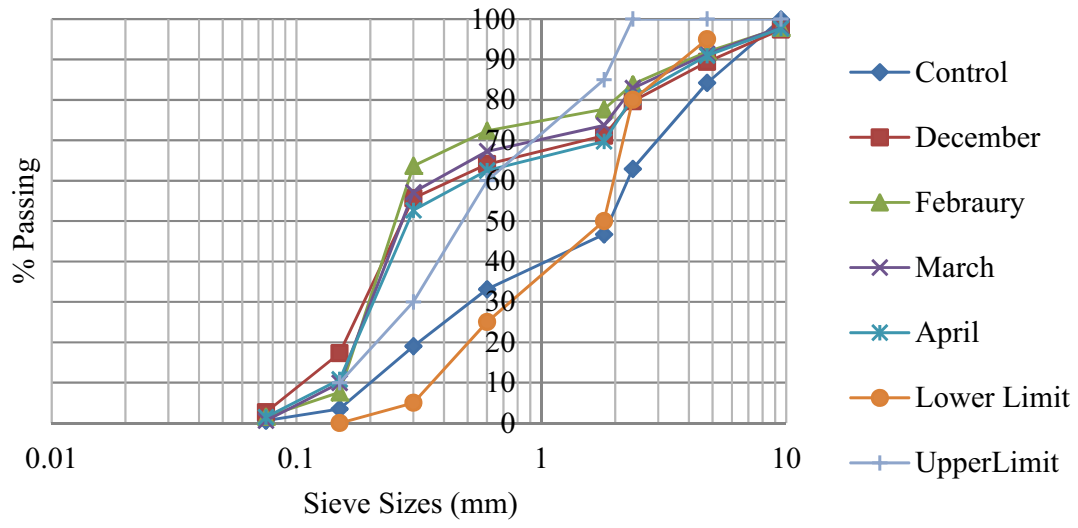

(d) Grade 5

Fig. 4 Sieve analysis of RA and virgin (control) aggregate.

gravity values of Grade 5, which may have resulted from the addition of asphalt to increase its selling value.

Values obtained from the evaluation of the physical and mechanical properties of RA were compared against the values obtained from the same evaluation process conducted on virgin aggregate, as shown in Table 3 . The results showed that RA has higher absorption capacity due to the mortar adhered on the surface, higher abrasion loss, high crushing value, and soundness loss which could be attributed to previous exposure to weathering and loading.

\subsection{Phase 2: Evaluation of Concrete Properties Prepared with Different Grade Combinations}

In this phase, extensive evaluation was conducted to select the grade combinations as-delivered that could be used in concrete production to meet the target strength and durability requirements for different applications. Compressive strength, splitting tensile strength, flexural strength, and modulus of elasticity tests were performed to determine suitability of these mixes to different applications. Additionally, the rapid chloride penetration tests (RCPT) (Kwan et al. 2012) for all mixes 
and scanning electron microscopy (SEM) scans to examine the micro-structural features for selected samples were conducted to provide information about the long-term durability.

Materials Grades 1, 2, 4, and 5 as fine and coarse aggregates, in addition, type I cement were used in all mixes. No supplementary cementitious materials were used in the mixes; only high range water reducer admixture was used to achieve the target workability.

Control mix the mix proportioning is based on the absolute volume method to produce self-consolidated concrete (SCC). The main reason for selecting a SCC mix that issues related to workability and aggregate gradation could be emphasized with a SCC mix. In addition, if recycled aggregate (RA) could be used to produce SCC; hence, RA could be used for other mixes with target slump. The following volumetric ratios of $14 \%$ cement, $17.6 \%$ water (w/ $\mathrm{c}=0.4)$ and $68.4 \%$ aggregate. The aggregate percentage $(68.4 \%)$ was divided into $37.6 \%$ coarse aggregate (crushed lime stone) and $30.8 \%$ fine aggregate based on the optimization of packing density of normal weight fine and coarse aggregates used for the control mix. The target cube compressive strength was $50 \mathrm{MPa}(7000 \mathrm{psi})$ and total slump flow was $500 \mathrm{~mm}$ (20 in.) spread.

Packed density of $R A$ based on the volumetric ratios, the weight of grade 1, grade 2 and grade 5 were proportioned and collected in a measuring cylinder has a volume of

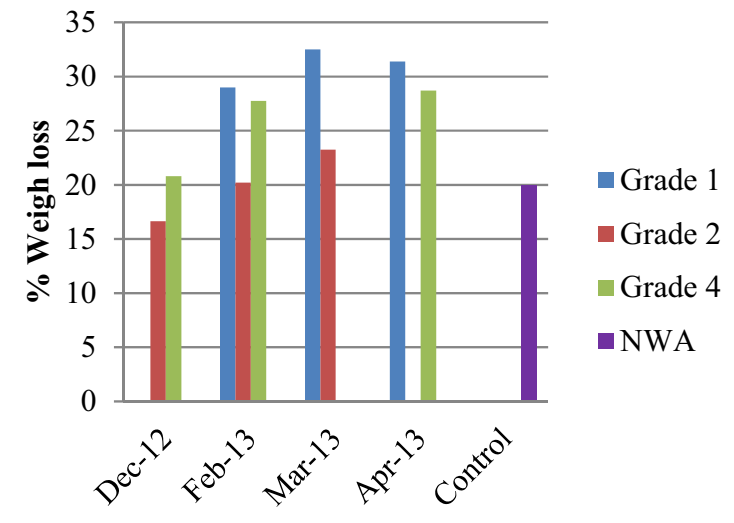

(a) Aggregate crushing value

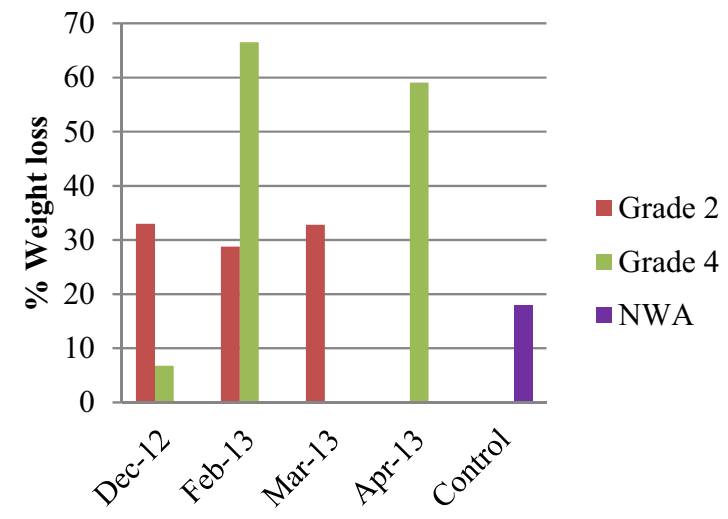

(b) Abrasion

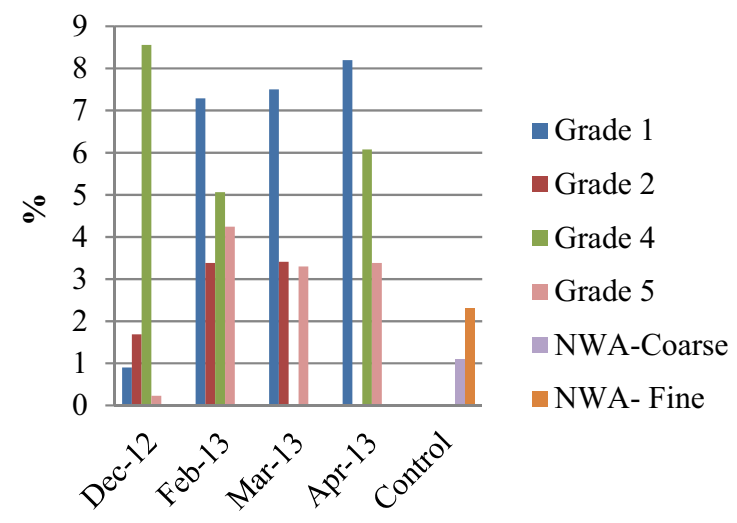

(c) Absorption

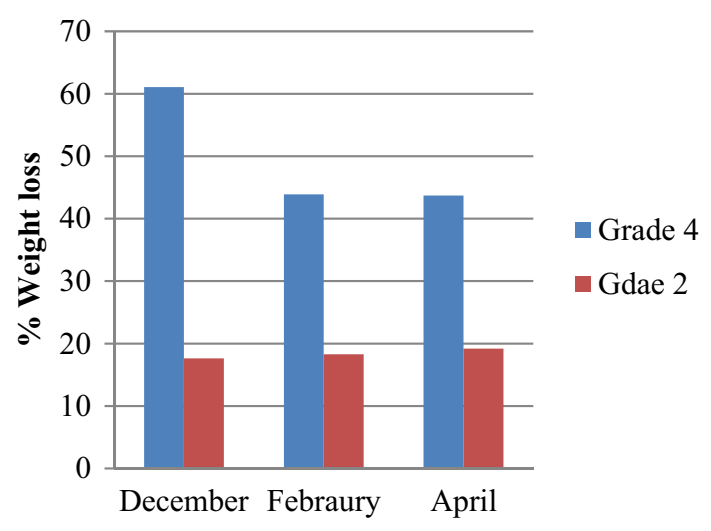

(d) Soundness test - Size $9.5 \mathrm{~mm}$

Fig. 5 Evaluation of physical and mechanical properties of RA. 


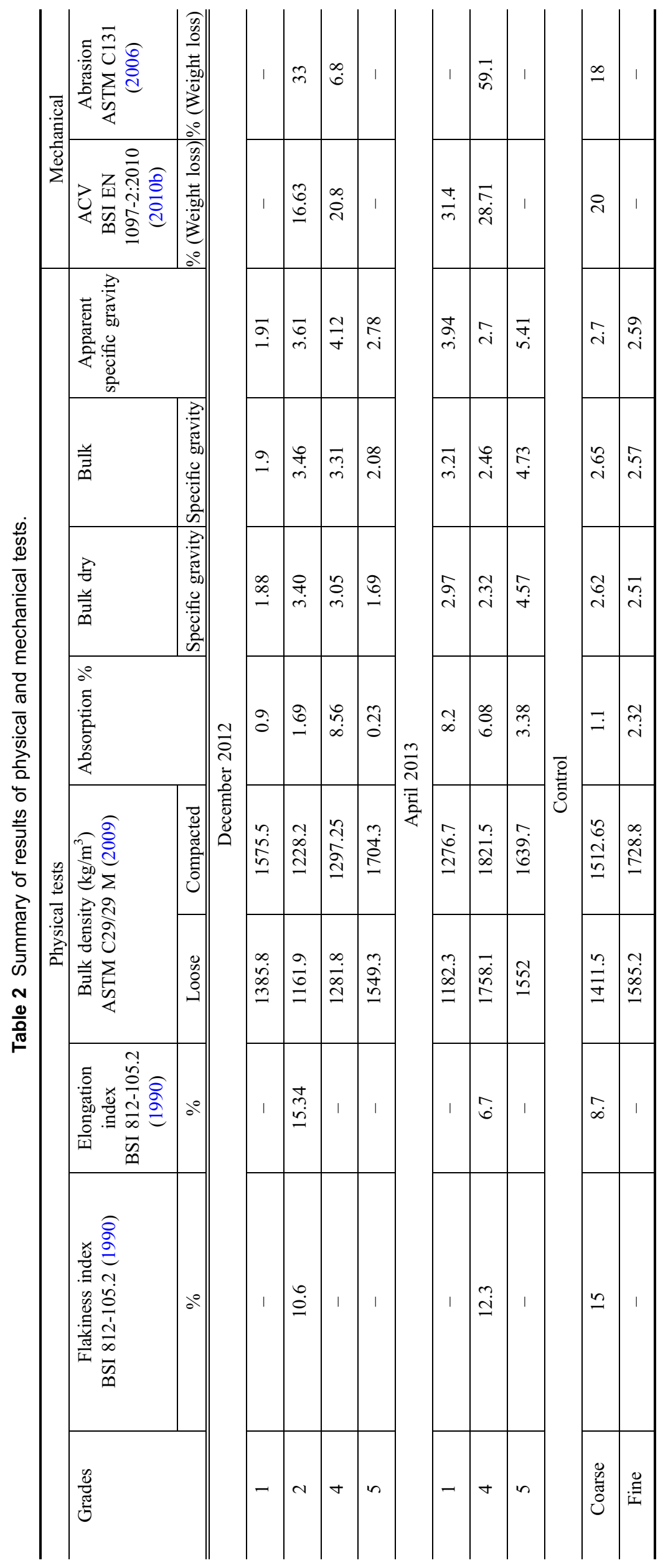

International Journal of Concrete Structures and Materials (Vol.9, No.2, June 2015) | 227 
Table 3 Summary of the tests results: Virgin and recycled aggregate properties.

\begin{tabular}{c|c|c}
\hline Property & Virgin aggregate & RA \\
\hline \hline Absorption & $1-2.5 \%$ & $2-4.5$ \\
\hline Specific gravity & $2.4-2.7$ & $20-35 \%$ \\
\hline Crushing value & $15-20 \%$ & $25-65 \%$ \\
\hline L.A abrasion & $15-30 \%$ & $5-36 \%$ \\
\hline Sodium sulfate soundness \\
(mass loss)
\end{tabular}

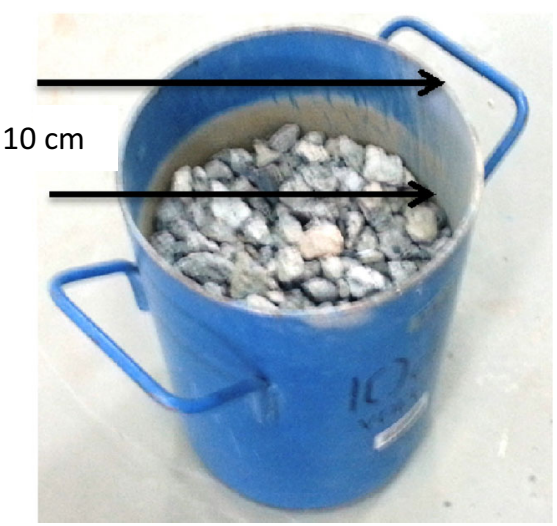

(a) Packed density

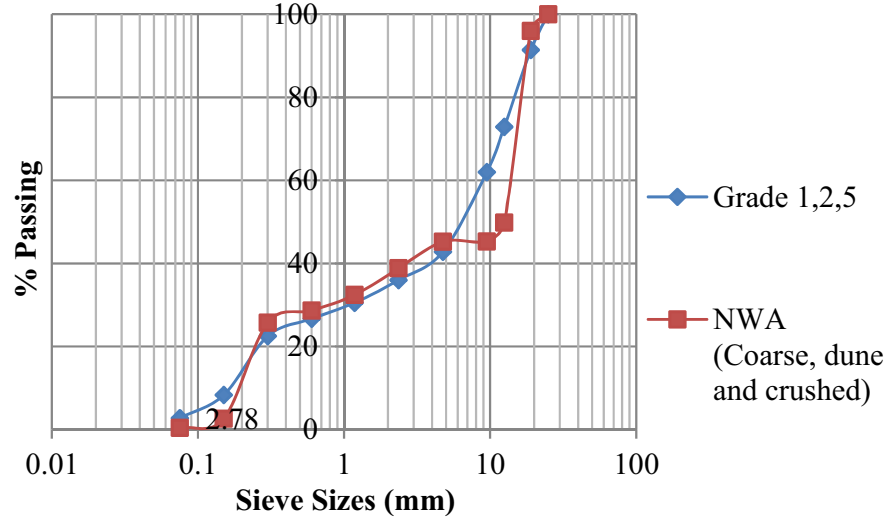

(b) Grade 1, 2, 5

Fig. 6 Evaluation of grades 1,2, 5 combined.

$10 \mathrm{dm}^{3}$ (cubic decimeters), which is equivalent to 101 . This cylinder is used in determining loose and compacted bulk density of aggregates according to ASTM C29/29 M (2009). The sum of the design volumes of these materials is $68.4 \%$ of the total volume; however, when the dry materials were placed and tamped in three layers, as shown in Fig. 6a, the materials occupied $68 \%$ of the volume. This indicates that the mix proportioning utilizing grades 1,2 and 5 leads to a dense matrix, which in turn should reflect on strength and durability performance.

Mix proportioning for recycled aggregate concrete the same volumetric ratios of the control mix was adopted for the recycled aggregate, however, since different grades of the recycled aggregate with different particle sizes were available, the following approach was considered in the current study: (i) in case of mixes contain grades 1 and 2, percentage of the coarse aggregate was divided to $50-50 \%$, (ii) mixes with grades 1,4 , and 5, 37.6\% of grade $4,15 \%$ of grade 1 and $15.8 \%$ of grade 5 were used. These ratios were verified according to the packed density as discussed before.

Water and moisture adjustment mixing water of different mixes was adjusted during the mix design stage according to the moisture content and percentage absorption of each grade included in a specific mix. In addition, the decision was to use the same quantity of the admixture used for the control mix and monitor the slump/flow for the mixes with recycled aggregate. The concrete mixes had the same water to cement ratio $(w / c)$ and cement content.
Several mixes were prepared utilizing four grades, grades $1,2,4$, and 5 of the recycled aggregate. Mixes were identified according to the grades used in each mix, for example, Mix 1,2,5 indicates that grade 1, grade 2 and grade 5 were used in that mix. Six mixes from the four grades were prepared in addition to the control mix.

\subsubsection{Fresh Stage Evaluation}

Table 4 summarizes the results of slump, air content, and unit weight, which were recorded immediately after every mix. All mixes achieved the target flow except Mix 1,5 because of the particle size and distribution. Figure 7 shows slump test for Mixes 1,2,5 and 1,5. Mix 1,4 produced the least unit weight, which could be attributed to the existence of mortar attached to the aggregate as shown in Fig. 3d. Air content varied between 0.8 and $2.4 \%$ for mixes with recycled aggregate, which indicates variation in aggregate gradation, particle size and distribution.

\subsubsection{Hardened Stage Evaluation: Mechanical and Microstructure Evaluation}

Table 4 summarizes the test results of splitting tensile strength and flexural strength for all mixes compared to the compressive strength. Results of split tensile and modulus of rupture from the current study were compared to corresponding equations from BSI EN 1097-2:2010 (2010b) and proposed equations by (Xiao et al. 2006). In addition, Table 5 shows typical failure modes of several samples from different mixes. 


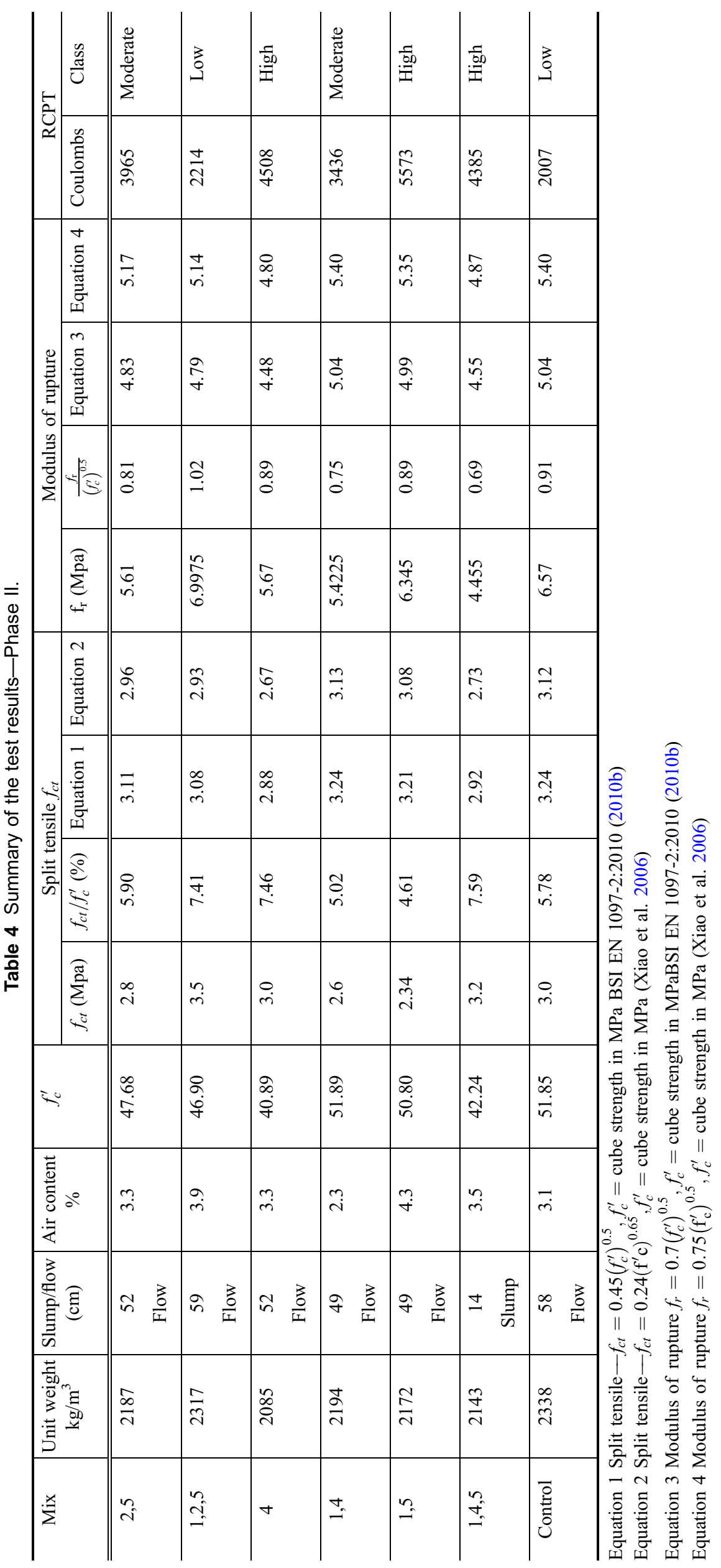




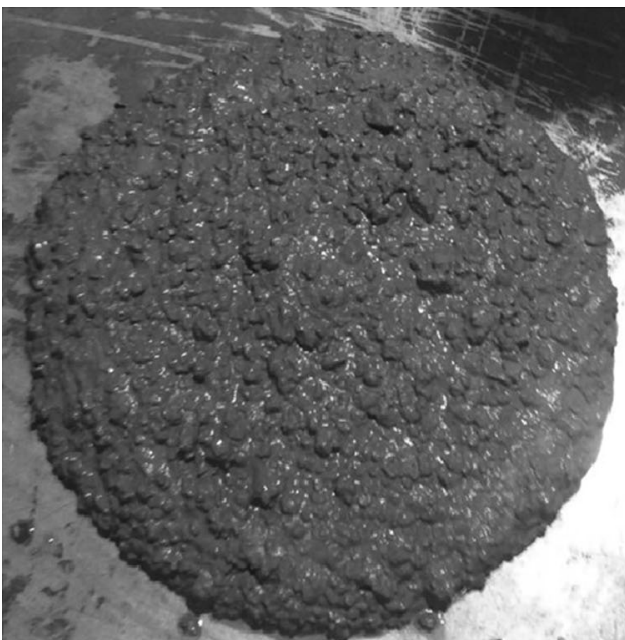

(a) Mix $1,2,5$

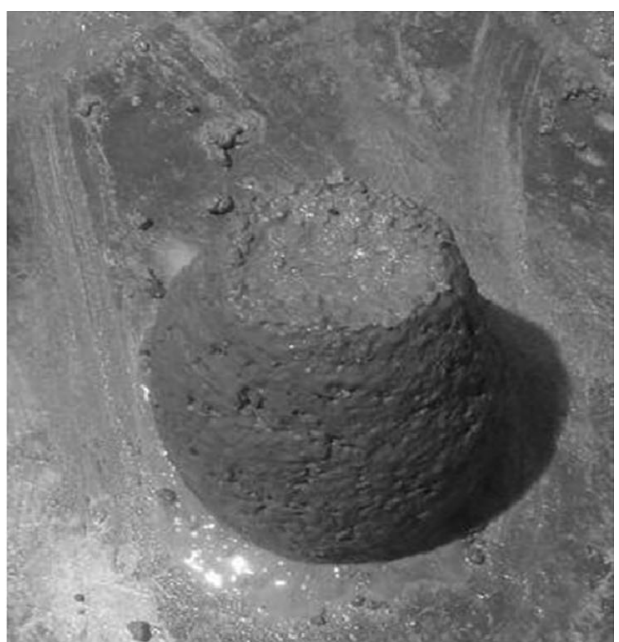

(b) Mix 1,5

Fig. 7 Fresh stage evaluation-Workability.

Compressive strength Cubes $(150 \mathrm{~mm} \times 150 \mathrm{~mm} \times$ $150 \mathrm{~mm}$ ) were tested for compressive strength according to (ASTM 2011a) at 3, 7, 14, 21, and 28 days, strength development with time is shown in Fig. 8. Compressive strength of concrete produced with the recycled aggregate was in the range of 41 to $52 \mathrm{MPa}$. Mix 4 had the lowest compressive strength. This was expected due to the nature of grade 4 , which has poor particle distribution and contains different impurities. Mix 1,4 and Mix 1,2,5 showed similar compressive strength to that of the control. Mix 1,4 consisted of grade $1(10 \mathrm{~mm})$ as coarse aggregate in addition to grade 4, which has different particle sizes varying from $20 \mathrm{~mm}$ and different distribution of fine aggregate. This aggregate gradation provided a dense matrix, which reduces the amount of voids within the mix leading to higher compressive strength. In Mix 1,2,5, grades 1, 2 and 5 provided good distribution of fine and coarse aggregate, which led to higher compressive strength and unit weight similar to that of the control mix. This was also supported by the sieve analysis and packed density as shown in Fig. 6. On the other hand, Mix 4 had the lowest strength out of all mixes due to the gap-gradation that shows an absence of an appropriate distribution of the coarse aggregate. Most of the aggregate sizes are either $20 \mathrm{~mm}$ coarse or fine aggregate. In addition, failure modes were observed during testing as shown in Table 5. All failure modes were similar to that of the control. Plane of failures did not go through the coarse aggregates, instead the failure was in the mortar or aggregates were pulled out during the flexural tests, as indicated in Table 5.

Splitting tensile strength Splitting tensile tests were conducted according to ASTM C496/C496 M (2011b) to determine indirect tensile strength of concrete. Mix 1,2,5 had the highest splitting tensile strength while Mix 1,5 showed the least splitting tensile strength at 28 days. The test results did not show a clear trend, which might be attributed to the aggregate distribution and particle size. However, values in Table 4 were in the range of $4.6-7.46 \%$ of the cube compressive strength, which is close to the range predicted by Eq. 1 (6-7 \%). Split tensile results calculated using Eq. 2 were different from those of the current study and Eq. 1. The predicted values are scattered and not close to the test data.

Flexural strength Third-point loading was applied on simple concrete prisms to determine the flexural strength for all mixes. Mix 1,2,5 and Mix 1,5 showed flexural strength higher or similar to that of the control mix. This could be attributed to the improved mechanical interlocking due to better bond between crushed coarse aggregate and cement paste. This was observed from the failure modes and cracking of aggregate as shown in Table 5. In addition, results in Table 4 showed that all mixes achieved flexural strength similar or higher than that predicted using Eq. 3. The average ratio of $f_{r} / \sqrt{f_{c}^{\prime}}$ is 0.85 which is higher than the 0.7 used in Eq. 3; however, it is closer to that proposed by Eq. 4.

Modulus of elasticity Several samples from each mix were tested to evaluate the stress-strain relationship and to calculate the modulus of elasticity values. The modulus of elasticity values were in the range of $25-28 \mathrm{GPa}$. This variation could be attributed to low aggregate strength and the variation of the volumetric ratio of the course aggregate (some grades have coarse aggregate within their distribution).

Rapid chloride penetration test (RCPT) Ability of concrete to resist chloride ion penetration at 60 voltage direct current (VDC) and $6 \mathrm{~h}$ of testing is taken as an indicator of the concrete durability. The results in Coulombs are summarized in 
Mix

$1,2,5$

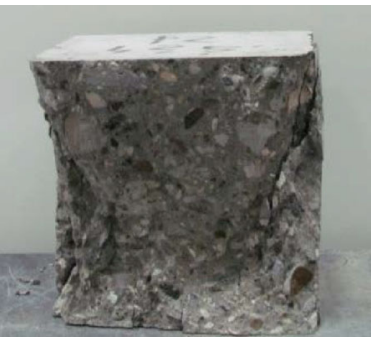

Flexure

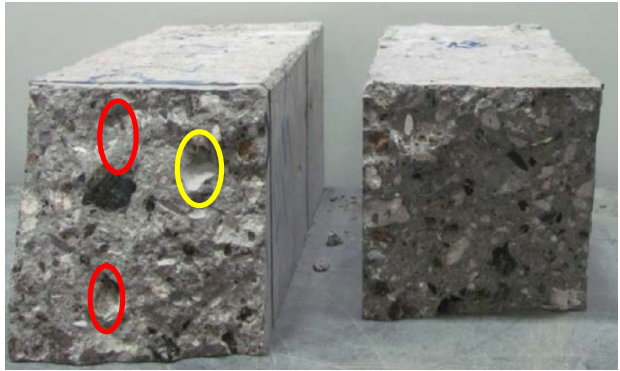

Split tension

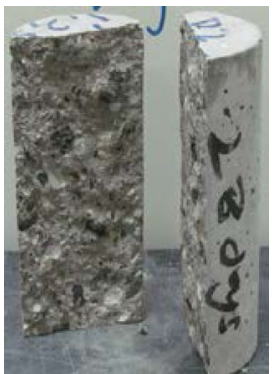

$\operatorname{Mix} 1,4$
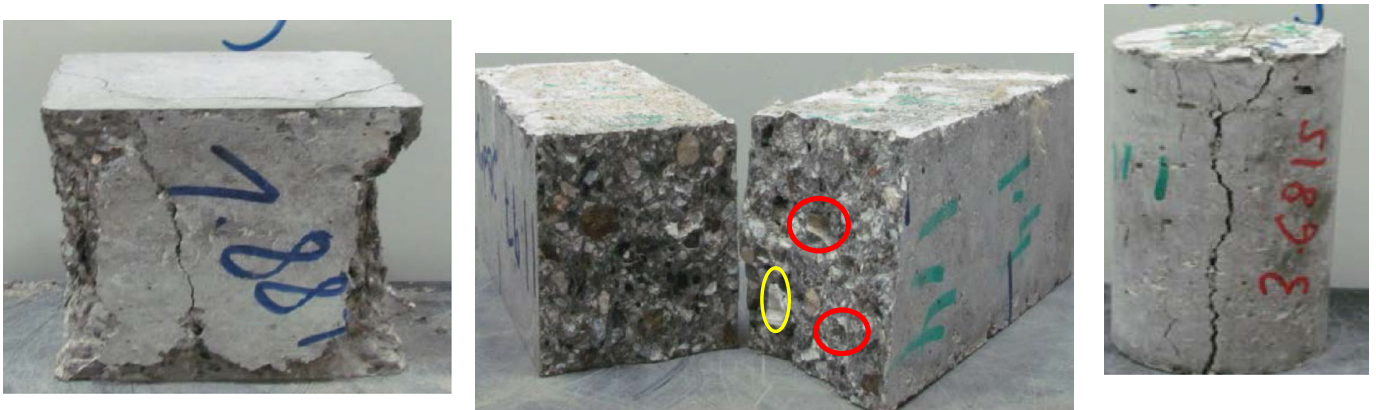

$1,4,5$
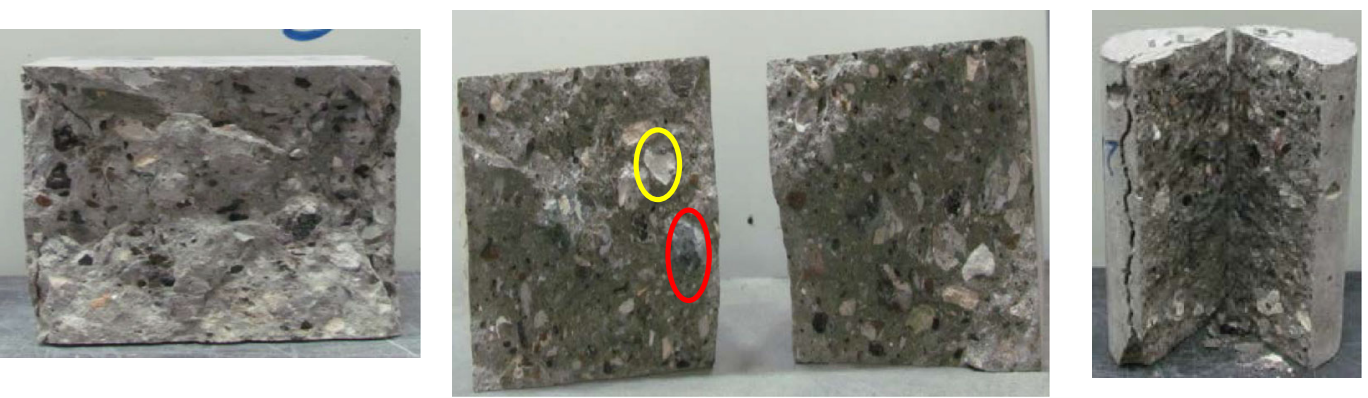

Control
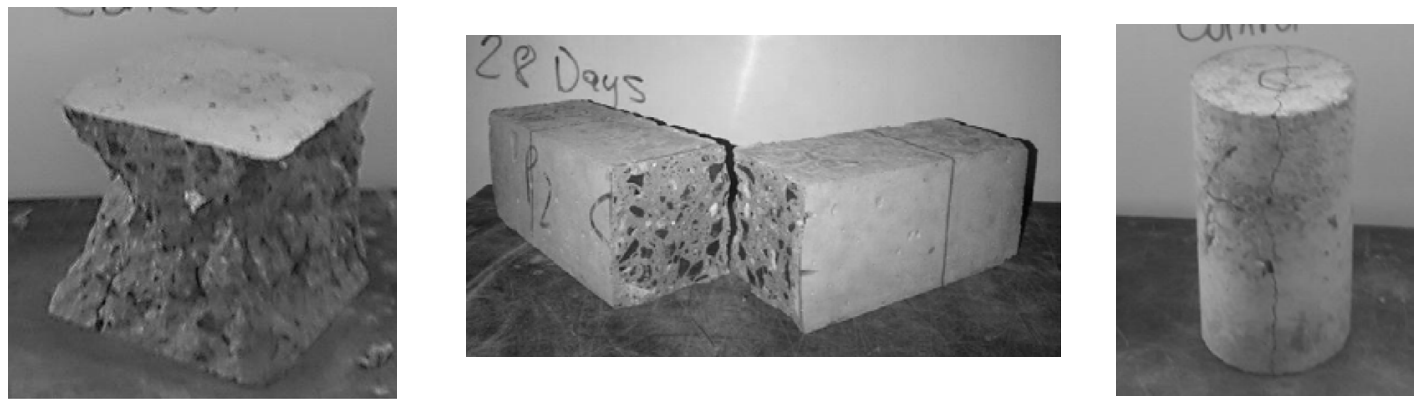

Table 4 and categorized according to ASTM C1202 (2012b). All mixes except Mix 1,2,5 had high or close to the upper boundary of moderate permeability which could be attributed to the poor aggregate distribution. On the other hand, Mix $1,2,5$ produced similar results to that of the control. The use of two different course aggregate distributions along with the fine aggregate led to a dense mix with less voids and better resistance to the chloride ion penetration.

\section{SEM Scan}

The SEM scans were conducted on samples of two mixes, which had high and low chloride ion permeability according to the RCPT classifications. Figure 9a shows a SEM scan for Mix 1,2,5 (low permeability mix), a good bond and no sign of the wall effect at the Interfacial Transition Zone (ITZ) between the cement paste and the recycled aggregate was 


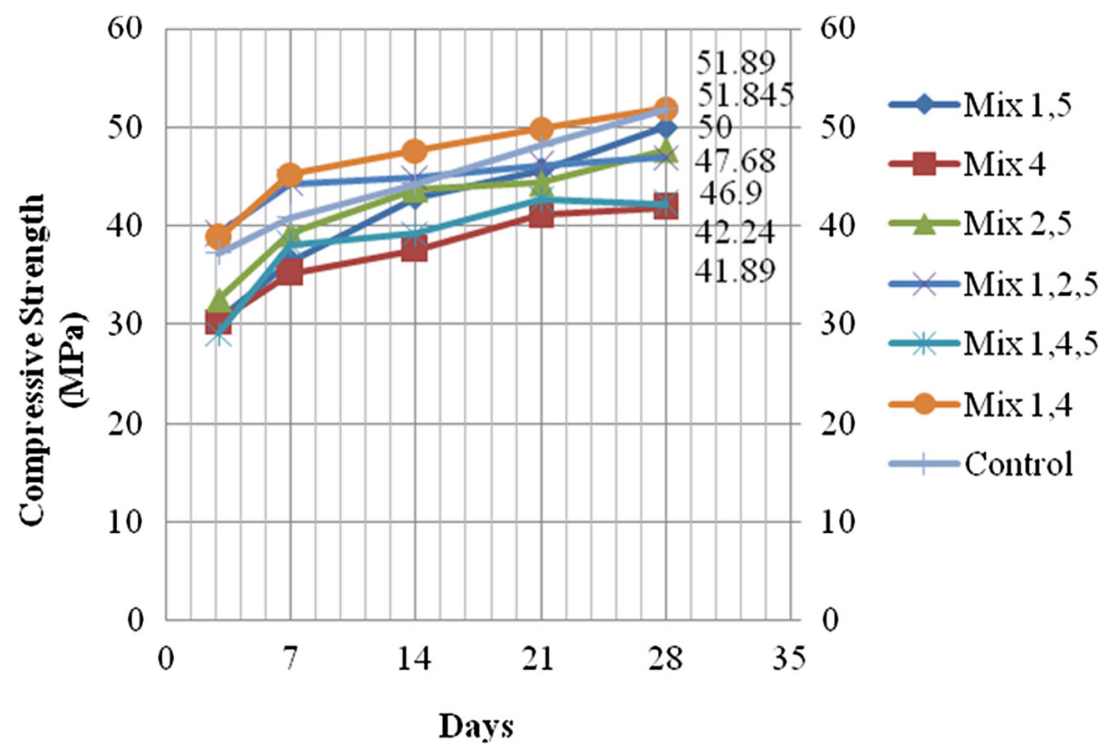

Fig. 8 Development of compressive strength with time-Phase II.

observed. On the hand, a close inspection to the SEM scans for Mix 1,5 in Fig. 9b (high permeability mix) shows that a porous layer exists between the aggregate and cement paste, which confirm the formation of the wall effect at ITZ in this mix. This layer, which could be cement hydrates, adhered to the coarse aggregate, in addition to different contaminants and voids contributed to the higher absorption and higher chloride ion permeability in this mix category. In both mixes, micro cracks (not due to sample preparation) were found in the cement paste; this type of cracks usually occur due to shrinkage and difference in modulus of elasticity between the paste and the coarse aggregate particles (Neville 1995).

\section{Discussion}

Results of Phase II evaluations showed that Mix 1,2,5 achieved acceptable compressive, flexural, and splitting tensile strength. In addition, it had the best performance in RCPT which was confirmed with the microstructure evaluation as shown in the SEM scans. The main reason of this performance was achieving high packing density by utilizing different grades. The high packing density provided solution for limitations in particle distribution and aggregate strength. This led to reduction in total pore volume which in turn improved the strength and durability of the mix. This also is in agreement with that reported by (Levy and Helene 2004; McNeil and Kang 2013). In addition, the absolute volume method used in the current study took into consideration variability in specific gravity of the RA during mix proportioning which led to improved properties. This is also in agreement with the findings by (Knaack and Kurama 2013). Examination of the SEM and crack propagation, Fig. 10, showed that cracks are initiated at the interface between the aggregates and mortar. Figure 10 shows that regardless of the sample shape the cracks started at the pours mortar adhered to the recycled aggregate. This indicates, in this case, a weakness of the old mortar which led to reduced bond between the old and new mortar. Similar behavior was discussed by (Tam et al. 2007a, b; Xiao et al. 2012a).

Table 6 provides a summary of the results from several investigations found in the literature compared to that of Mix $1,2,5$. The results included in Table 6 are only those of concrete mixes with $100 \%$ RA or from full replacement of coarse aggregate. No results of partial replacement of natural aggregate are included. Although the testing environment, aggregate source, and w/c ratios are different, there is a good agreement in all the mechanical properties. This summary emphasizes that concrete with similar results could be produced with recycled aggregate regardless the source of the aggregate. In addition, the following could be observed from over all the results in Table 6, (1) RA with high absorption capacity and low specific gravity lead to concrete with less compressive strength compared to target strength; (2) 7 to $15 \%$ reduction in compressive strength compared to target strength when $\mathrm{w} / \mathrm{cm}$ ratio is maintained in the range of 0.4 to 0.45 ; (3) flexural and splitting strength varied based on the $\mathrm{w} / \mathrm{c}$ ratio and aggregate source and (4) reduction of about 10 to $15 \%$ in the modulus of elasticity. 

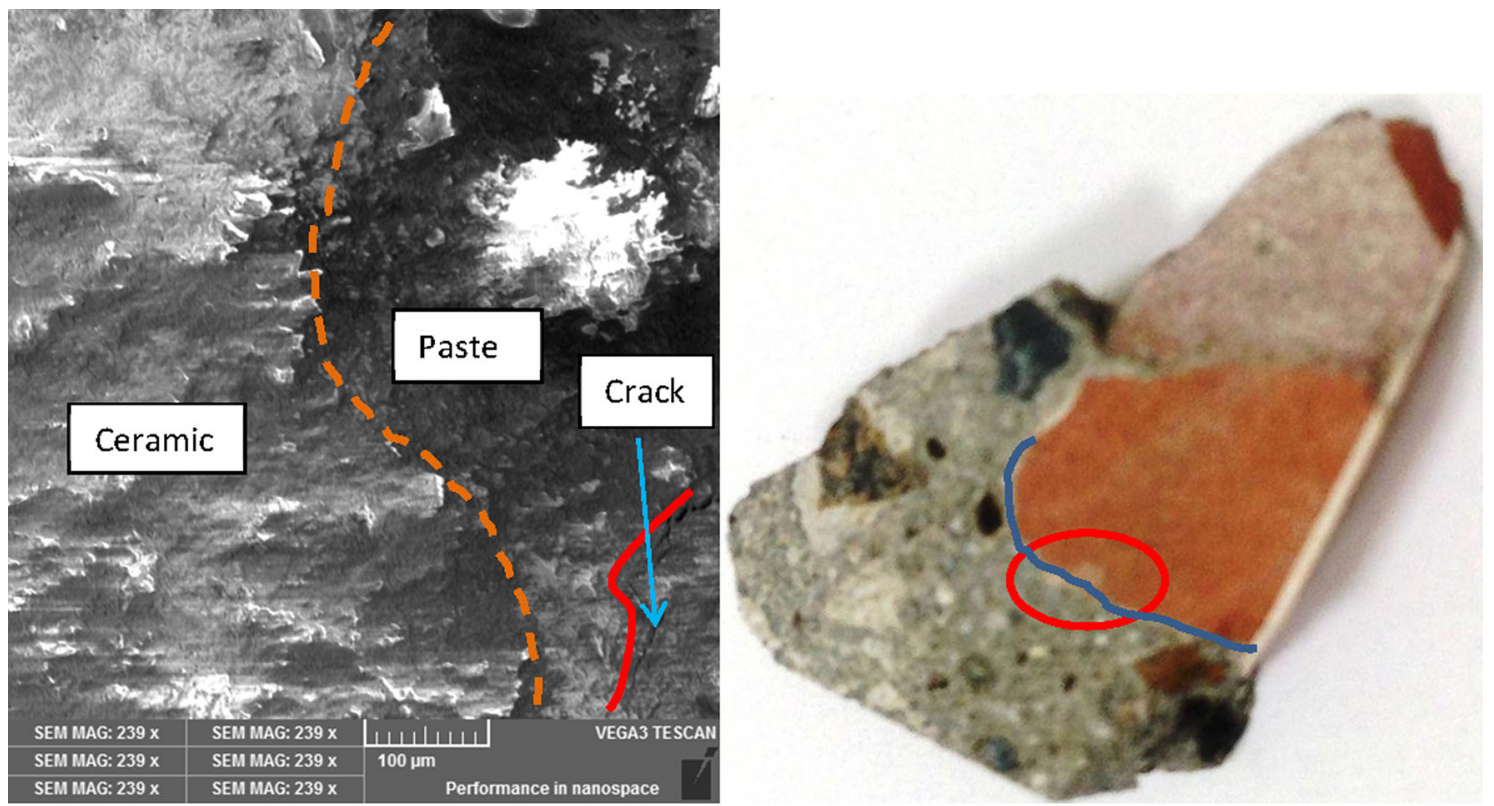

(a) Aggregate - cement paste interaction-Mix 1,2,5

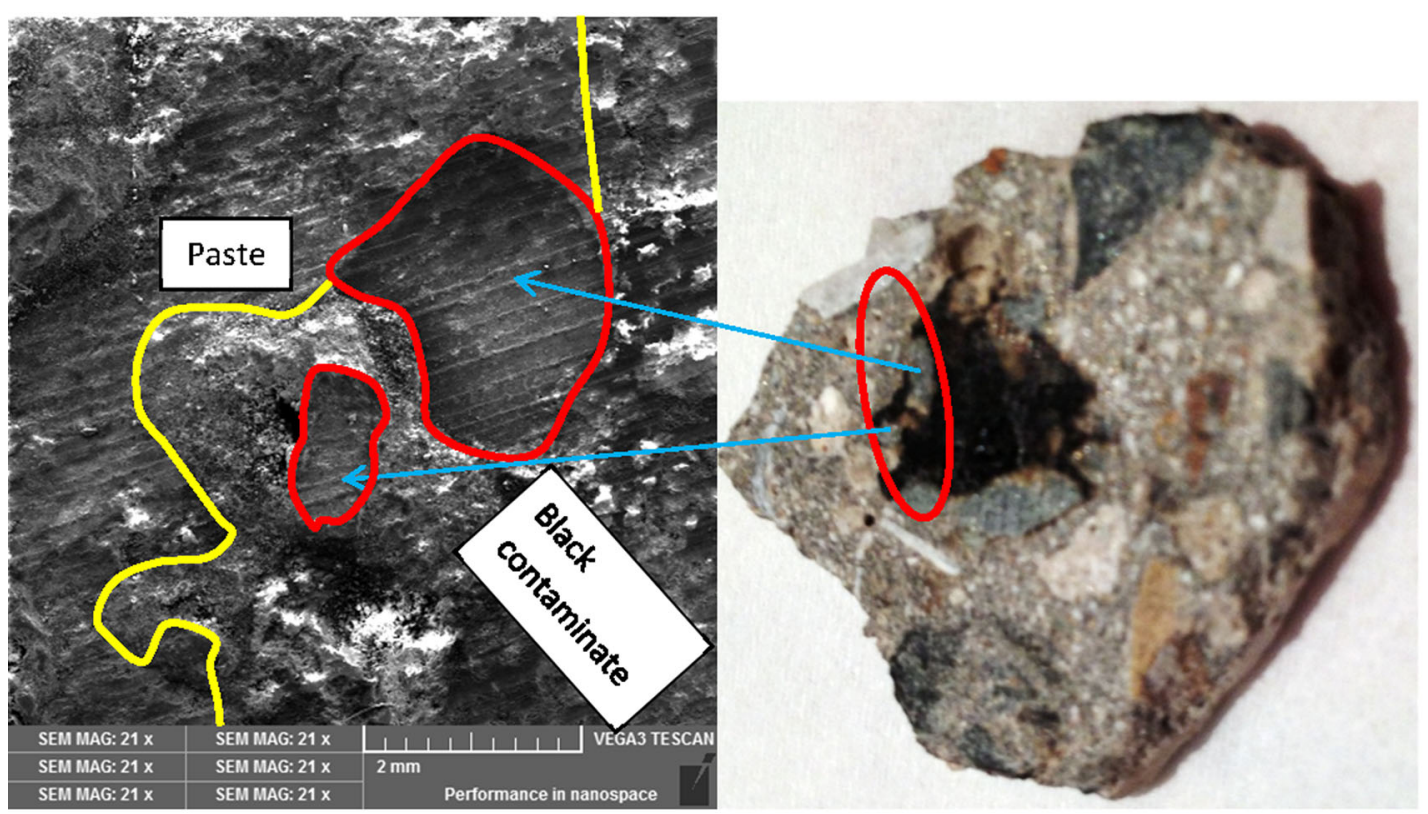

(b) Aggregate - cement paste interaction- Mix 1,5

Fig. 9 SEM features of concrete with recycled aggregate.

\subsection{Recommendations from the Current Study}

The following recommendations could be drawn from the study:

- For every batch of recycled aggregate:

- Particle size and distribution should be evaluated every batch
- Absorption capacity, abrasion resistance, and soundness are important properties that need to be evaluated.

- Mixture design method based on direct volume replacement and high packing density is the key to achieve strength and durable concrete. 


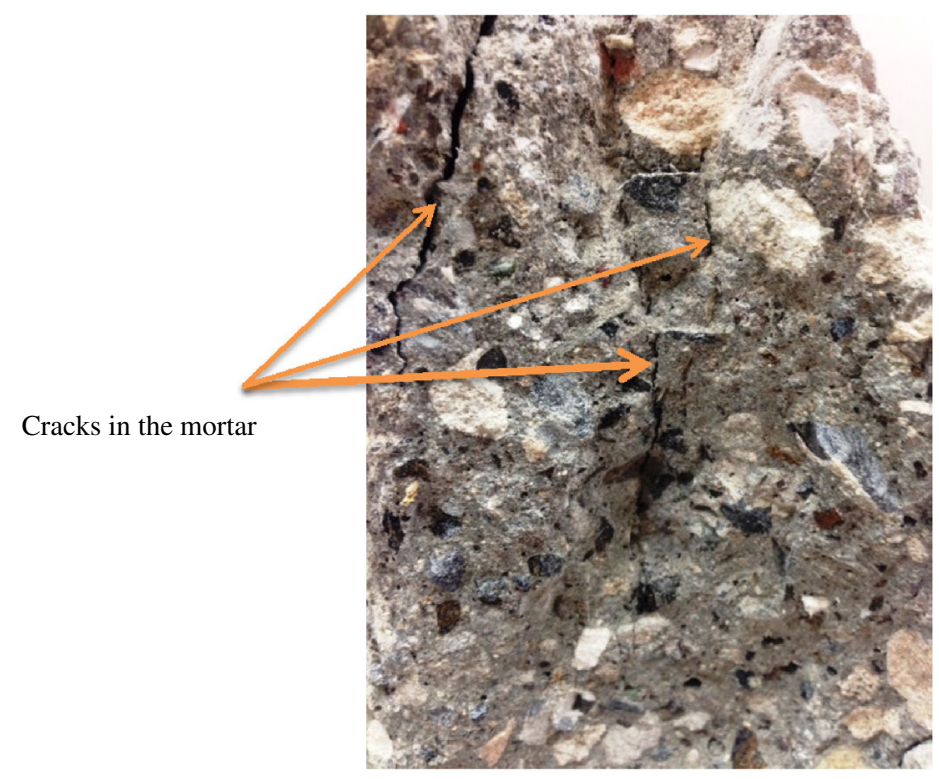

(a) Cylinder sample

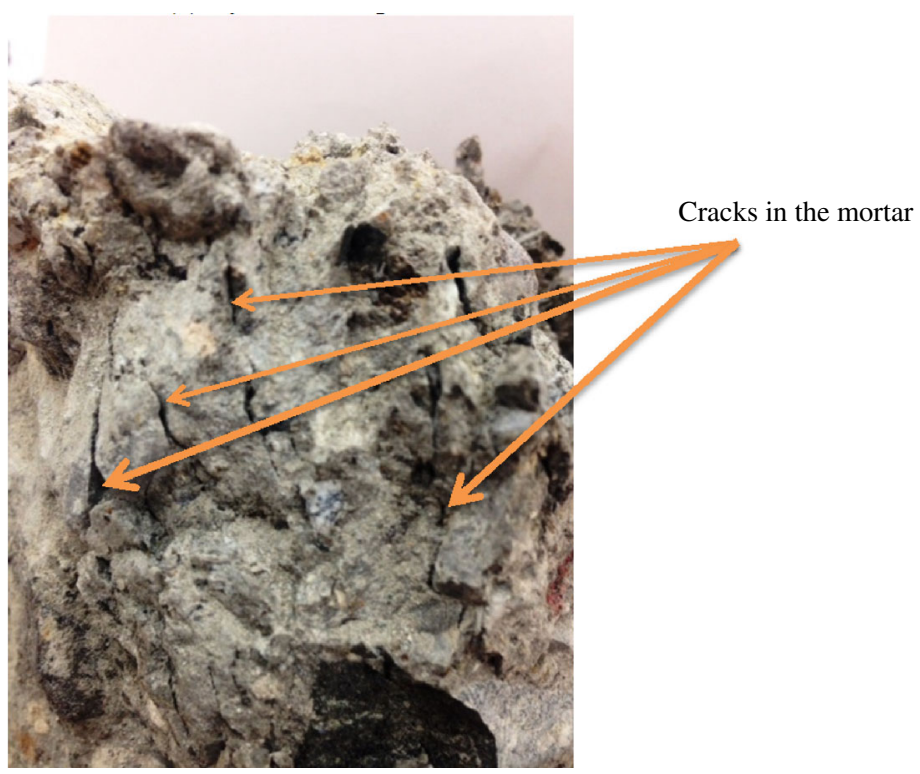

(b) Cube sample

Fig. 10 Crack initiation and propagation in RA concrete.

- $w / c$ ratio $\leq 0.4$ is preferred to improve strength and durability of concrete with RA

- Effect of SCM and high packing density on strength and durability of concrete with RA need to be investigated.

\section{Conclusions}

The work presented in this paper evaluates the effect of recycled aggregate quality on the properties of concrete. Evaluation of the aggregate physical and mechanical properties showed an acceptable variation in properties when samples were collected and evaluated from unknown source over 6 months. However, limitations in gradation requirements; high absorption and aggregate strength could be resolved during the proportioning stage and by achieving high packing density. Furthermore, concrete produced utilizing different combination of coarse and fine aggregate without alteration in particle size or distribution showed that comparable compressive, flexural, splitting strength, and modulus of elasticity could be achieved. All mixes except Mix 1,2,5 did not show acceptable performance in the RCPT because of the high porosity supported by the examination of the microstructure of the hardened concrete. High concrete porosity and permeability might be attributed to the variability in aggregate gradation and existence of contamination. It is also important to monitor the long-term performance and volume change (creep and shrinkage) to have better assessment of the concrete produced with recycled aggregate. 
Table 6 Comparison with available data from literature.

\begin{tabular}{|c|c|c|c|c|c|c|}
\hline Reference & $\begin{array}{c}\% \text { of target } \\
\text { compressive } \\
\text { strength }(\mathrm{MPa})\end{array}$ & $\begin{array}{l}\text { Flexural strength } \\
(\mathrm{MPa})\end{array}$ & Split tensile $(\mathrm{MPa})$ & Elasticity (GPa) & $\mathrm{w} / \mathrm{c}$ ratio & Aggregate source \\
\hline $\begin{array}{c}\text { Mix 1,2,5 } \\
\text { Current study }^{\mathrm{b}}\end{array}$ & $93.8(50)$ & 6.99 & 3.48 & 27 & 0.40 & Recycling facility \\
\hline $\begin{array}{c}\text { De Brito and Saikia } \\
(2013)^{\mathrm{b}}\end{array}$ & 88 (N/A) & 5.0 & 3.3 & 26.7 & 0.50 & C and D Waste \\
\hline \multirow{11}{*}{$\begin{array}{l}\text { Vivian A. Ulloa } \\
\text { et al. }(2013)^{\mathrm{a}}\end{array}$} & & & & & & C and D Waste \\
\hline & $-(31.4)$ & \multirow{2}{*}{\multicolumn{3}{|c|}{$\mathrm{X}$}} & 0.51 & \multirow{2}{*}{$\begin{array}{l}6.1 \% \text { Abs- } \\
\text { Demolition of old } \\
\text { concrete structure }\end{array}$} \\
\hline & $-(26)$ & & & & 0.61 & \\
\hline & $-(36.7)$ & \multirow{2}{*}{\multicolumn{3}{|c|}{$\mathrm{X}$}} & 0.51 & \multirow[t]{2}{*}{$5.8 \% \mathrm{Abs}$} \\
\hline & $-(29.5)$ & & & & 0.62 & \\
\hline & $-(42.9)$ & \multirow{2}{*}{\multicolumn{3}{|c|}{$\mathrm{X}$}} & 0.45 & \multirow[t]{2}{*}{$3.9 \% \mathrm{Abs}$} \\
\hline & $-(37.7)$ & & & & 0.54 & \\
\hline & $-(38.7)$ & \multirow{2}{*}{\multicolumn{3}{|c|}{$\mathrm{X}$}} & 0.4 & \multirow[t]{2}{*}{$4.5 \% \mathrm{Abs}$} \\
\hline & $-(31.4)$ & & & & 0.5 & \\
\hline & $-(37)$ & \multirow{2}{*}{\multicolumn{2}{|c|}{$X$}} & & 0.43 & \multirow[t]{2}{*}{$4.7 \% \mathrm{Abs}$} \\
\hline & $-(31.2)$ & & & & 0.56 & \\
\hline $\begin{array}{l}\text { Abdelfatah et al. } \\
\qquad(2011)^{\mathrm{b}}\end{array}$ & $85.7(42)$ & $\mathrm{X}$ & $X$ & $\mathrm{X}$ & 0.40 & $\begin{array}{l}\text { Old concrete with } \\
\text { known strength }\end{array}$ \\
\hline $\begin{array}{l}\text { Malešev et al. } \\
\qquad(2010)^{\mathrm{a}}\end{array}$ & $91.3(50)$ & 5.2 & 2.78 & 29.1 & 0.513 & $\begin{array}{c}\text { Crushed laboratory } \\
\text { test cubes }\end{array}$ \\
\hline $\begin{array}{l}\text { Tabsh and } \\
\text { Abdelfatah } \\
(2009)^{\mathrm{b}}\end{array}$ & $92(50)$ & $\mathrm{X}$ & 4 & $\mathrm{X}$ & 0.40 & $\begin{array}{l}\text { Old concrete with } \\
\text { known strength }\end{array}$ \\
\hline $\begin{array}{l}\text { Corinaldesi and } \\
\text { Moriconi }(2009)^{\mathbf{b}}\end{array}$ & $89(28)$ & $\mathrm{X}$ & 1.45 & 27 & 0.4 & $\begin{array}{c}\text { Rubble Recycling } \\
\text { Plant }\end{array}$ \\
\hline $\begin{array}{l}\text { Yang et al. } \\
(2008)^{\mathrm{a}}-\mathrm{G} 1\end{array}$ & $90(36.0)$ & 3.84 & 3.49 & 29.22 & 0.42 & $\begin{array}{l}\text { Old concrete with } \\
\text { unknown strength }\end{array}$ \\
\hline $\begin{array}{l}\text { Yang et al. } \\
(2008)^{\mathrm{a}}-\mathrm{G} 3\end{array}$ & $73.75(29.5)$ & 3.20 & 2.56 & 23.72 & 0.42 & $\begin{array}{c}\mathrm{G} 1-\mathrm{SG} 2.53- \\
1.9 \% \text { Abs } \\
\mathrm{G} 3-\mathrm{SG} 2.4- \\
6.2 \% \mathrm{Abs}\end{array}$ \\
\hline Rahal $(2007)^{\mathrm{a}}$ & $93(50)$ & $\mathrm{X}$ & $\mathrm{X}$ & 29.5 & 0.6 & $\begin{array}{l}\text { Field demolished } \\
\text { concrete }\end{array}$ \\
\hline $\begin{array}{l}\text { Etxeberria et al. } \\
\qquad(2007)^{\mathrm{b}}\end{array}$ & $93.3(30)$ & $\mathrm{X}$ & 2.72 & 27.76 & 0.52 & $\begin{array}{l}\text { Selected and } \\
\text { processed for the } \\
\text { study }\end{array}$ \\
\hline \multirow{6}{*}{$\begin{array}{l}\text { Etxeberria et al. } \\
\qquad(2007)^{\mathrm{a}}\end{array}$} & $93.3(28)$ & $\mathrm{X}$ & 2.72 & 27.76 & 0.50 & $\mathrm{C}$ and D Waste \\
\hline & $78.3(47)$ & & & & 0.50 & \multirow[t]{5}{*}{$\mathrm{C}$ and D Waste } \\
\hline & $85(51)$ & & & & 0.43 & \\
\hline & $93.3(56)$ & & & & 0.40 & \\
\hline & $93.3(56)$ & & & & 0.40 & \\
\hline & $66.7(40)$ & & & & 0.52 & \\
\hline $\begin{array}{c}\text { Limbachiya et al. } \\
(2004)^{\mathrm{a}}\end{array}$ & $94(35)$ & 4.5 & $X$ & 25 & 0.6 & $\mathrm{C}$ and D Waste \\
\hline
\end{tabular}


Table 6 continued

\begin{tabular}{c|c|c|c|c|c|c}
\hline Reference & $\begin{array}{c}\text { \% of target } \\
\text { compressive } \\
\text { strength (MPa) }\end{array}$ & $\begin{array}{c}\text { Flexural strength } \\
(\mathrm{MPa})\end{array}$ & Split tensile (MPa) & Elasticity (GPa) & w/c ratio & Aggregate source \\
\hline Katz $(2003)^{\mathrm{b}}$ & $77.46(26.8)$ & 5.4 & 3.1 & 11.3 & 0.60 & $\begin{array}{c}\text { Old concrete with } \\
\text { known strength }\end{array}$ \\
\hline
\end{tabular}

${ }^{\mathrm{a}}$ Coarse aggregate replacement.

b Full replacement.

- Target strength is not available.

$S G$ Specific gravity, Abs Absorption capacity.

\section{Open Access}

This article is distributed under the terms of the Creative Commons Attribution 4.0 International License (http:// creativecommons.org/licenses/by/4.0/), which permits unrestricted use, distribution, and reproduction in any medium, provided you give appropriate credit to the original author(s) and the source, provide a link to the Creative Commons license, and indicate if changes were made.

\section{References}

Abbas, A., Fathifazl, G., Isgor, O. B., Razaqpur, A. G., Fournier, B., \& Foo, S. (2009). Durability of recycled aggregate concrete designed with equivalent mortar volume method. Cement \& Concrete Composites, 31(8), 555-563.

Abdelfatah, A., Tabsh, S., \& Yehia, S. (2011). Utlilization of recycled coarse aggregate in concrete mixes. Journal of Civil Engineering and Architecture, 5(6), 562-566.

Akbarnezhad, A., Ong, K. C. G., Tam, C. T., \& Zhang, M. H. (2013). Effects of the parent concrete properties and crushing procedure on the properties of coarse recycled concrete aggregates. Journal of Materials in Civil Engineering, 25(12), 1795-1802.

Amorim, P., De Brito, J., \& Evangelista, L. (2012). Concrete made with coarse concrete aggregate: Influence of curing on durability. ACI Materials Journal, 109(2), 195.

Ann, K. Y., Moon, H. Y., Kim, Y. B., \& Ryou, J. (2008). Durability of recycled aggregate concrete using pozzolanic materials. Waste Management, 28(6), 993-999.

Ann, T. W., Poon, C. S., Wong, A., Yip, R., \& Jaillon, L. (2013). Impact of construction waste disposal charging scheme on work practices at construction sites in Hong Kong. Waste Management, 33(1), 138-146.

ASTM C131. (2006). Standard test method for resistance to degradation of small-size coarse aggregate by abrasion and impact in the Los Angeles machine. West Conshohocken, PA: ASTM International.

ASTM C29/29 M. (2009). Standard test method for bulk density (unit weight) and voids in aggregate. West Conshohocken, PA: ASTM International.

ASTM C78/C78 M-10e1. (2010). Standard test method for flexural strength of concrete (using simple beam with third- point loading). West Conshohocken, PA: ASTM International.

ASTM C136. (2011a). Standard test method for sieve analysis of fine and coarse aggregates ASTM West Conshohocken, PA: ASTM International.

ASTM C496/C496 M. (2011b). Standard test method for splitting tensile strength of cylindrical concrete specimens. West Conshohocken, PA: ASTM International.

ASTM C127. (2012a). Standard test method for density, relative density (specific gravity), and absorption of coarse aggregate. West Conshohocken, PA: ASTM International.

ASTM C1202. (2012b). Standard test method for electrical indication of concrete's ability to resist chloride ion penetration. West Conshohocken, PA: ASTM International.

ASTM C33/C33. M (2013a). Standard specification for concrete aggregates. West Conshohocken, PA: ASTM International.

ASTM C88. (2013b). Standard test method for soundness of aggregates by use of sodium sulfate or magnesium sulfate. West Conshohocken, PA: ASTM International.

Berndt, M. L. (2009). Properties of sustainable concrete containing fly ash, slag and recycled concrete aggregate. Construction and Building Materials, 23(7), 2606-2613.

Bodet, R. (2014). Review French/European standards and regulations. 08/07/2014 http://navier.enpc.fr/IMG/pdf/Standards_and _regulation_R-BODET.pdf.

Braunschweig, A., Kytzia, S., \& Bischof, S. (2011). Recycled concrete: Environmentally beneficial over virgin concrete?, www.lcm2011.org.

BSI EN 12390-6:2009. (2010a). Testing hardened concrete Compressive strength of test specimens. British Standard Institute.

BSI EN 1097-2:2010. (2010b). Tests for mechanical and physical properties of aggregates: Methods for the determination of resistance to fragmentation. London, UK: British Standards Institute.

BSI 812-105.2. (1990). Method for determination of particle size: Elongation index of coarse aggregate. London, UK: British Standard Institute.

Cabral, A. E. B., Schalch, V., Dal Molin, D. C. C., \& Ribeiro, J. L. D. (2010). Mechanical properties modeling of recycled aggregate concrete. Construction and Building Materials, 24(4), 421-430.

Cement, Concrete, and Aggregates (2008). Use of recycled aggregate. Australia: Hong Kong Housing Authority. 
Chen, H.-G., \& Ying, J.-W. (2011). Analysis of factors influencing durability of recycled aggregate: A review. Paper presented at the electric technology and civil engineering, Lushan.

Chen, Z.-P., Huang, K.-W., Zhang, X.-G., \& Xue, J.-Y. (2010). Experimental research on the flexural strength of recycled coarse aggregate concrete. Paper presented at the 2010 international conference on mechanic automation and control engineering (MACE), Wuhan, China.

Corinaldesi, V. (2010). Mechanical and elastic behaviour of concretes made of recycled-concrete coarse aggregates. Construction and Building Materials, 24(9), 1616-1620. doi:10.1016/j.conbuildmat.2010.02.031.

Corinaldesi, V., \& Moriconi, G. (2009). Influence of mineral additions on the performance of $100 \%$ recycled aggregate concrete. Construction and Building Materials, 23(8), 2869-2876.

De Brito, J., \& Saikia, N. (2013). Recycled aggregate in concrete: Use of industrial, construction and demolition waste. 445 p., London, UK: Springer.

de Juan, M. S., \& Gutiérrez, P. A. (2009). Study on the influence of attached mortar content on the properties of recycled concrete aggregate. Construction and Building Materials, 23(2), 872-877.

EU. Directive 2008/98/EC of the European Parliament and the Council of 19 November 2008 on waste and repealing certain Directives. European Union.

Domingo-Cabo, A., Lázaro, C., López-Gayarre, F., SerranoLópez, M. A., Serna, P., \& Castaño-Tabares, J. O. (2009). Creep and shrinkage of recycled aggregate concrete. Construction and Building Materials, 23(7), 2545-2553.

Eisa, A. (2014). Properties of concrete incorporating recycled post-consumer environmental wastes. International Journal of Concrete Structures and Materials, 8(3), 251-258.

Etxeberria, M., Vazques, E., Mari, A., \& Barra, M. (2007). Influence of amount of recycled coarse aggregates and production process on properties of recycled aggregate concrete. Cement and Concrete Research, 37(5), 735-742.

European Aggregate Association. (2010). Planning policies and permitting procedures to ensure the sustainable supply of aggregates in Europe. Austria: University of Leoben.

Evangelista, L., \& Brito, J. D. (2007). Mechanical behaviour of concrete made with fine recycled concrete aggregates. $\mathrm{Ce}$ ment \& Concrete Composites, 29(5), 397-401. doi: 10.1016/j.cemconcomp.2006.12.004.

Fathifazl, G., \& Razaqpur, A. G. (2013). Creep rheological models for recycled aggregate concrete. ACI Materials Journal, 110(2), 115-126.

Fathifazl , G., Abbas, A., Razaqpur, A. G., Isgor, O. B., Fournier, B., \& Foo, S. (2009). New mixture proportioning method for concrete made with coarse recycled concrete aggregate. Journal of Materials in Civil Engineering, 21(10), 601-611.

Fathifazl, G., Razaqpur, A. G., Isgor, O. B., Abbas, A., Fournier, B., \& Foo, S. (2011). Creep and drying shrinkage characteristics of concrete produced with coarse recycled concrete aggregate. Cement \& Concrete Composites, 33(10), 1026-1037.
Garg, P., Singh, H., \& Walia, B. S. (2013). Optimum Size of Recycled Aggregate. GE-International Journal of Engineering Research. pp. 35-41, ISSN:2321-1717

Gonclaves, A., Esteves, A., \& Vieira, M. (2004). Influence of recycled concrete aggregate on concrete durability. Paper presented at the National Laboratory of Civil Engineering, Portugal.

Gupta, Y. P. (2009). Use of recycled aggregate in concrete construction: A need for sustainable environment. Paper presented at the our world in concrete and structures, Singapore.

Hansen, T. C. (1986). Recycled aggregates and recycled aggregate concrete second state-of-the-art report developments 1945-1985. Materials and Structures, 19(3), 201-246.

Henschen, J., Teramoto, A., \& Lange, D. A. (2012, January). Shrinkage and creep performance of recycled aggregate concrete. In 7th RILEM international conference on cracking in pavements (pp. 1333-1340). Springer Netherlands.

Kartam, N., Al-Mutairi, N., Al-Ghusain, I., \& Al-Humoud, J. (2004). Environmental management of construction and demolition waste in Kuwait. Waste Management, 24(10), 1049-1059.

Katz, A. (2003). Properties of concrete made with recycled aggregate from partially hydrated old concrete. Cement and Concrete Research, 33(5), 703-711.

Knaack, A. M., \& Kurama, Y. C. (2013). Design of concrete mixtures with recycled concrete aggregates. ACI Materials Journal, 110(5), 483-493.

Kou, S. C., \& Poon, C. S. (2012). Enhancing the durability properties of concrete prepared with coarse recycled aggregate. Construction and Building Materials, 35, 69-76.

Kwan, W. H., Ramli, M., Kam, K. J., \& Sulieman, M. Z. (2012). Influence of the amount of recycled coarse aggregate in concrete design and durability properties. Construction and Building Materials, 26(1), 565-573.

Lederle, R. E., \& Hiller, J. E. (2013). Reversible shrinkage of concrete made with recycled concrete aggregate and other aggregate types. ACI Materials Journal, 110(4), 423.

Levy, S. M., \& Helene, P. (2004). Durability of recycled aggregates concrete: A safe way to sustainable development. Cement and Concrete Research, 34(11), 1975-1980.

Limbachiya, M. C., Koulouris, A., Roberts, J. J., \& Fried, A. N. (2004). Performance of Recycled Concrete Aggregate. Paper presented at the RILEM international symposium on environmental-conscious materials and systems for sustainable development

Llatas, C. (2011). A model for quantifying construction waste in projects according to the European waste list. Waste Management, 31(6), 1261-1276.

Lu, W., \& Tam, V. W. (2013). Construction waste management policies and their effectiveness in Hong Kong: A longitudinal review. Renewable and Sustainable Energy Reviews, 23, 214-223.

Lu, W., \& Yuan, H. (2011). A framework for understanding waste management studies in construction. Waste Management, 31(6), 1252-1260.

Malešev, M., Radonjanin, V., \& Marinković, S. (2010). Recycled concrete as aggregate for structural concrete 
production. Sustainability, 2(5), 1204-1225. doi:10.3390/ su2051204.

Manzi, S., Mazzotti, C., \& Bignozzi, M. C. (2013). Short and long-term behavior of structural concrete with recycled concrete aggregate. Cement \& Concrete Composites, 37, 312-318.

Marinkovic, S., Radonjanin, V., Malesev, M., \& Ignjatovic, I. (2010). Comparative environmental assessment of natural and recycled aggregate concrete. Waste Management, Elsevier, 30(11), 2255-2264.

McNeil, K., \& Kang, T. H.-K. (2013). Recycled concrete aggregates: A review. International Journal of Concrete Structures and Materials, 7(1), 61-69.

Medina, C., Zhu, W., Howind, T., Sanchez de Rojas, M. I., \& Frias, M. (2014). Influence of mixed recycled aggregate on the physical-mechanical properties of recycled concrete. Journal of Cleaner Production, 68(1), 216-225.

Ministry of Natural Resources (2010). State of the aggregate resource in Ontario study. Toronto, Canada: Queen's Printer for Ontario.

Naik, T. R., \& Moriconi, G. (2005) Environmental-friendly durable concrete made with recycled materials for sustainable concrete construction CANMET/ACI international symposium on sustainable development of cement and concrete, Toronto, Canada, October 2005 (pp. 1-13).

Neville, A. M. (1995). Properties of concrete. Harlow, NY: Pearson.

Oikonomou, N. D. (2005). Recycled concrete aggregates. Cement \& Concrete Composites, 27(2), 315-318.

Olorunsogo, F. T., \& Padayachee, N. (2002). Performance of recycled aggregate concrete monitored by durability indexes. Cement and Concrete Research, 32(2), 179-185.

Otsuki, N., Miyazato, S. I., \& Yodsudjai, W. (2003). Influence of recycled aggregate on interfacial transition zone, strength, chloride penetration and carbonation of concrete. Journal of Materials in Civil Engineering, 15(5), 443-451.

Padmini, A. K., Ramamurthy, K., \& Mathews, M. S. (2009). Influence of parent concrete on the properties of recycled aggregate concrete. Construction and Building Materials, 23(2), 829-836. doi:10.1016/j.conbuildmat.2008.03.006.

Poon, C. S., Shui, Z. H., \& Lam, L. (2004). Effect of microstructure of ITZ on compressive strength of concrete prepared with recycled aggregates. Construction and Building Materials, 18(6), 461-468.

Qasrawi, H., \& Marie, I. (2013). Towards better understanding of concrete containing recycled concrete aggregate. $A d-$ vances in Materials and Science Engineering. doi: $10.1155 / 2013 / 636034$.

Rahal, K. (2007). Mechanical properties of concrete with recycled coarse aggregate. Building and Environment, 42(1), 407-415. doi:10.1016/j.buildenv.2005.07.033.

Rao, M. C., Bhattacharyya, S. K., \& Barai, S. V. (2010). Recycled aggregate concrete: A sustainable built environment. Paper presented at the ICSBE: International conference on sustainable built environment.

Ryou, J. S., \& Lee, Y. S. (2014). Characterization of recycled coarse aggregate (RCA) via a surface coating method.
International Journal of Concrete Structures and Materials, 8(2), 165-172.

Sagoe-Crentsil, K., Brown, T., \& Taylor, A. H. (2001). Performance of concrete made with commercially produced coarse recycled concrete aggregate. Cement and Concrete Research, 31(5), 707-712. doi:10.1016/S0008-8846(00)00476-2.

Silva, R. V., De Brito, J., \& Dhir, R. K. (2014). Properties and composition of recycled aggregates from construction and demolition waste suitable for concrete production. Construction and Building Materials, 65, 201-217.

Silva, R. V., de Brito, J., \& Dhir, R. K. (2015). Prediction of the shrinkage behavior of recycled aggregate concrete: A review. Construction and Building Materials, 77, 327-339.

Sim, J., \& Park, C. (2011). Compressive strength and resistance to chloride ion penetration and carbonation of recycled aggregate concrete with varying amount of fly ash and fine recycled aggregate. Waste Management, 31(11), 2352-2360. doi:10.1016/j.wasman.2011.06.014.

Sonawane, T. R., \& Pimplikar, S. S. (2013). Use of recycled aggregate in concrete. International Journal of Engineering Research and Technology (IJERT), 2(1), 1-9.

Tabsh, S. W., \& Abdelfatah, A. S. (2009). Influence of recycled concrete aggregates on strength properties of concrete. Construction and Building Materials, 23(2), 1163-1167. doi:10.1016/j.conbuildmat.2008.06.007.

Tam, V. W. Y. (2008). Economic comparison of concrete recycling: A case study approach. Elsevier, 52(5), 821-828.

Tam, V. W., Gao, X. F., \& Tam, C. M. (2005). Microstructural analysis of recycled aggregate concrete produced from twostage mixing approach. Cement and Concrete Research, 35(6), 1195-1203.

Tam, V. W., Gao, X. F., Tam, C. M., \& Chan, C. H. (2008). New approach in measuring water absorption of recycled aggregates. Construction and Building Materials, 22(3), 364-369.

Tam, V. W. Y., \& Tam, C. M. (2007). Economic comparison of recycling over-ordered fresh concrete: A case study approach. Resources, Conservation and Recycling, 52(2), 208-218. doi:10.1016/j.resconrec.2006.12.005.

Tam, V. W., Tam, C. M., \& Le, K. N. (2007a). Removal of cement mortar remains from recycled aggregate using presoaking approaches. Resources, Conservation and Recycling, 50(1), 82-101.

Tam, V. W., Tam, C. M., \& Wang, Y. (2007b). Optimization on proportion for recycled aggregate in concrete using twostage mixing approach. Construction and Building Materials, 21(10), 1928-1939.

Tepordei, V. V. (1999). Natural aggregates-Foundation of America's future. USGS: Science for a changing world.

The Freedonia Group. (2012). World Construction Aggregates.

Thomas, C., Setien, J., Polanco, J. A., Alaejos, P., \& Sanchez de Juan, M. (2013). Durability of recycled concrete aggregate. Construction and Building Materials, 40, 1054-1065.

Topcu, I. B., \& Guncan, N. F. (1995). Using waste concrete as aggregate. Cement and Concrete Research, 25(7), 1385-1390. doi:10.1016/0008-8846(95)00131-U.

Transportation Applications of Recycled Concrete AggregateFHWA State of the Practice National Review 2004; U.S. 
Department of Transportation Federal Highway Administration: Washington, DC, 2004; pp. 1-47.

Ulloa, V. A., García-Taengua, E., Pelufo, M. J., Domingo, A., \& Serna, P. (2013). New views on effect of recycled aggregates on concrete compressive strength. ACI Materials Journal, 110(6), 1-10.

Vyas, C. M., \& Bhatt, D. R. (2013). Evaluation of modulus of elasticity for recycled coarse aggregate concrete. International Journal of Engineering Science and Innovative Technology, 2(1), 26.

Wardeh, G., Ghorbel, E., \& Gomart, H. (2014). Mix design and properties of recycled aggregate concretes: Applicability of Eurocode 2. International Journal of Concrete Structures and Materials, 9(1), 1-20.

Xiao, J., Li, W., Sun, Z., \& Shah, S. P. (2012a). Crack propagation in recycled aggregate concrete under uniaxial compressive loading. ACI Materials Journal, 109(4), $451-462$.

Xiao, J., Fana, L. Y., \& Huang, X. (2012b). An overview of study on recycled aggregate concrete in China (1996-2011).
Construction and Building Materials, 31, 364-383. doi: 10.1016/j.conbuildmat.2011.12.074.

Xiao, J., Li, L., Tam, V. W., \& Li, H. (2014). The state of the art regarding the long-term properties of recycled aggregate concrete. Structural Concrete, 15(1), 3-12.

Xiao, J. Z., Li, J. B., \& Zhang, C. (2006). On relationships between the mechanical properties of recycled aggregate concrete: An overview. Materials and Structures, 39(6), 655-664.

Yang, K. H., Chung, H. S., \& Ashour, A. F. (2008). Influence of type and replacement level of recycled aggregates on concrete properties. ACI Materials Journal, 105(3), 289-296.

Yehia, S., Khan, S., \& Abudayyeh, O. (2008). Evaluation of mechanical properties of recycled aggregate for structural applications. HBRC Journal, 4(3), 7-16.

Zaharieva, R., Buyle-Bodin, F., Skoczylas, F., \& Wirquin E. (2003). Assessment of the surface permeation properties of recycled aggregate concrete. Cement and Concrete Composites, 25(2), 223-232. doi:10.1016/S0958-9465(02)00010-0 